\title{
Towards resolving the double classification in Erythraeus (Actinotrichida: Erythraeidae): matching larvae with adults using 28S sequence data and experimental rearing
}

\author{
Jeanette Stålstedt $^{1,2}$ • Andreas Wohltmann ${ }^{3} \cdot$ Johannes Bergsten $^{1} \cdot$ Joanna Mąkol $^{4}$
}

Received: 28 November 2015 / Accepted: 24 April 2016/Published online: 10 May 2016

(C) The Author(s) 2016. This article is published with open access at Springerlink.com

\begin{abstract}
The taxonomy of free-living adults and heteromorphic parasitic larvae of Parasitengona mites has in the past been treated independently resulting in a double classification. Correct linkage of names still remains unknown for many species. A holistic understanding of species is imperative for understanding their role in ecosystems. This is particularly true for groups like parasitengone mites with a radically altered lifestyle during development-parasitic to predatory. Here, we infer linkages of three nominal species of Erythraeus, using matching with $28 \mathrm{~S}$ DNA sequence data from field-collected specimens and through laboratory rearing. The general mixed Yule coalescent method (GMYC) was used to explicitly test if field-collected specimens representing heteromorphic life instars were conspecific. The field-collected larvae were allocated to adults of Erythraeus cinereus and Erythraeus regalis, respectively. Laboratory rearing of the same two species confirmed the matching done by DNA. Rearing was also successful for Erythraeus phalangoides after eggs were treated to an imitated winter diapause. This integrative
\end{abstract}

Joanna Mąkol

joanna.makol@up.wroc.pl

1 Department of Zoology, Swedish Museum of Natural History, Box 50007, 10405 Stockholm, Sweden

2 Department of Zoology, Stockholm University, 106 91 Stockholm, Sweden

3 Findorfstrasse 11, 27721 Ritterhude, Germany

4 Department of Invertebrate Systematics and Ecology, Institute of Biology, Wrocław University of Environmental and Life Sciences, Kożuchowska 5b, 51-631 Wrocław, Poland taxonomic approach of molecular, morphological, and rearing data resulted in the following synonyms: E. phalangoides (De Geer, 1778) [= Erythraeus adrastus (Southcott, 1961), syn. nov.], E. cinereus (Dugès, 1834) [= Erythraeus jowitae Haitlinger, 1987, syn. nov.], and E. regalis (C.L. Koch, 1837) [= Erythraeus kuyperi (Oudemans, 1910), syn. nov., = Erythraeus gertrudae Haitlinger, 1987, syn. nov.]. The molecular evidence confirmed the separate identity of three further members of the genus. We provide redescriptions of E. phalangoides, E. cinereus, and E. regalis after modern standards, and neotypes are designated.

Keywords Biology $\cdot$ GMYC $\cdot$ Molecular species delimitation $\cdot$ Morphology $\cdot$ New synonyms $\cdot$ Parasitengona

\section{Introduction}

Few organisms look like small exact copies of the sexually mature adult already at birth, that is, some changes other than just isometric growth are commonly associated with the development from juvenile to adult organism. With great change, e.g., through metamorphosis, species-level identification will rely on completely different sets of morphological or anatomical characters for different life history forms. For the huge diversity of arthropods, with vast numbers still to be discovered and described (Erwin 1982; Basset et al. 2012), it is not surprising that most are known exclusively from a single life history form. For arthropods in general, this is commonly the adult but for various groups it can be the larval form (e.g., vertebrate parasitizing Trombiculidae). Connecting a species' life history forms, especially 
when biology changes substantially through development, is of course immensely important for understanding a species function in its ecosystem. As an example, malaria control efforts would look very different today if the life history forms of its vector were not connected. A particular problem arises if separate scientific schools, or scientists during different time periods, name life history forms in isolation of each other's work. This results in a "double classification"-many of the separate adult and larval names must be conspecific since they are based on the same regional fauna but to infer the correct linkage is non-trivial (Laydanowicz and Makol 2010). Such is the current situation for erythraeid mites where in the past the taxonomy was largely based on adults but more recently has been based on the parasitic larval forms (Makol and Wohltmann 2012).

One of the most speciose terrestrial parasitengone genera, Erythraeus Latreille, 1806 (Actinotrichida: Parasitengona, Erythraeidae), comprises over 100 (121) nominal species. However, the number of nominal species assigned to the genus today might differ substantially from the true number. A vast majority has been described either from larvae or active postlarval forms (deutonymph and/or adult). Hitherto, 43 larval and 50 postlarval names have been accommodated in the subgenus Erythraeus, whereas all 26 species in the subgenus Zaracarus Southcott, 1995 are solely known from larvae (Kamran et al. 2011, 2013; Mąkol and Wohltmann 2012, 2013; Kamran and Alatawi 2014; Mahmoudi et al. 2014; Haitlinger and Šundić 2015; Šundić et al. 2015a, b). Only two species, namely Erythraeus nipponicus Kawashima, 1961 and Erythraeus styriacus Turk, 1981, are known from both larvae and adults.

Until recently, the only available method to match larvae and postlarval forms of parasitengone mites was experimental rearing of field-collected ovigerous females or of parasitic larvae (Southcott 1961). Because of sampling effort, captivity stress, and the complexity of factors influencing parasitengone life cycles, such attempts have been rarely performed for Erythraeidae in the past (Mąkol and Wohltmann 2012, 2013).

Molecular methods for species identification now offer alternative ways to both study trophic interactions and to correlate life history forms of species (see Kress et al. 2015 for a recent review). Since the seminal paper by Hebert et al. (2003), this is broadly referred to as DNA barcoding, although in its strict sense, this term only applies to when certain standard genetic markers are being used (mitochondrial COI in animals). Larvaladult matching using DNA has been successfully applied to fish (Hubert et al. 2010; Baldwin and Johnson 2014 and references therein), amphibians (Vences et al. 2005), various invertebrate groups (Jousson et al. 1999;
Locke et al. 2011; Okassa et al. 2012; Alcántar-Escalera et al. 2013) including crustaceans (Feller et al. 2013), and a range of insect groups such as beetles (Miller et al. 2005; Caterino and Tishechkin 2006; Ahrens et al. 2007; Levkanicova and Bocak 2009; Lefort et al. 2012), Lepidoptera (Prado et al. 2011), Diptera (Pfenninger et al. 2007; Sutou et al. 2011), caddisflies (Johanson 2007; Zhou et al. 2007; Waringer et al. 2008), mayflies (Gattolliat and Monaghan 2010), stoneflies (Mynott et al. 2011; Avelino-Capistrano et al. 2014), and hemipterans (Zhang et al. 2008; Zhang and Weirauch 2011) to name a few. The main challenge is the unavailability of reference sequences of adults (Pfenninger et al. 2007) or insufficient field sampling of both life instars. Limited amount of DNA that can be obtained from relatively small specimens requires DNA extraction from the entire specimen. However, non-destructive methods of DNA extraction make it possible to retain the exoskeleton for voucher slide preparation (Cruickshank 2002; Dabert et al. 2008). Another challenge can be that the selected molecular marker is not variable enough for species-level identification. This can be due to that the marker itself is conservative with a slow substitution rate or that the species group is relatively young (Hickerson et al. 2006; Bergsten et al. 2012). Mitochondrial genes, like the animal COI barcode, can also portray false species identifications (and false adult-larval linkages) due to hybridization among species and introgression (Whitworth et al. 2007). Despite these challenges, and along with the relatively low cost and time expense, the technique offers an alternative to rearing and is indeed one of the most useful applications of DNA barcoding (Hebert and Gregory 2005; Kress et al. 2015).

In the present study, we test the validity of different Erythraeus species described independently as larvae and adult instars. Two separate methods are used to increase the accuracy in adult-larval linkage and to evaluate the applicability of molecular analysis compared with experimental rearing in terrestrial parasitengone mites. As a consequence of the results, we provide redescriptions for Erythraeus phalangoides (De Geer, 1778), Erythraeus cinereus (Dugès, 1834), and Erythraeus regalis (C.L. Koch, 1837), along with a list of new junior synonyms and neotype designations.

\section{Material and methods}

\section{Collecting, mounting, and morphological studies}

Larvae and adults of Erythraeus spp. were collected at different localities throughout Sweden, Germany and Poland. Data 


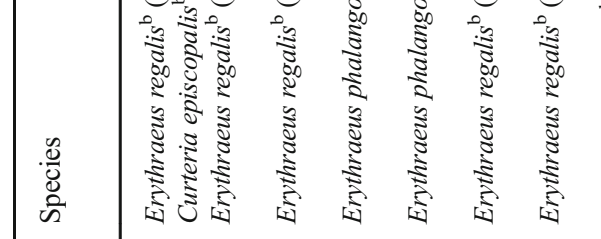

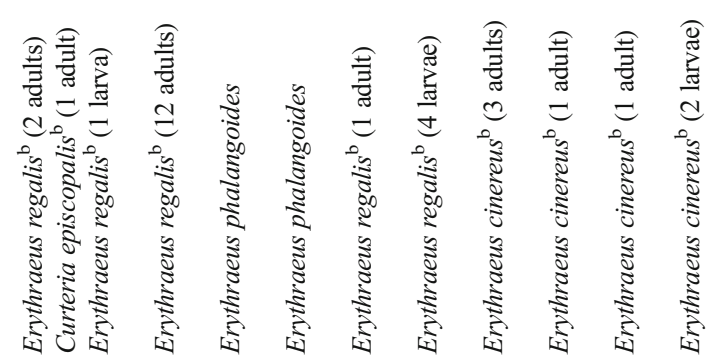
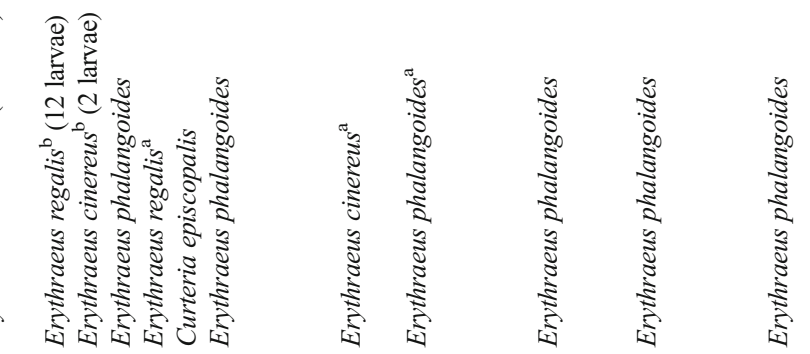

业

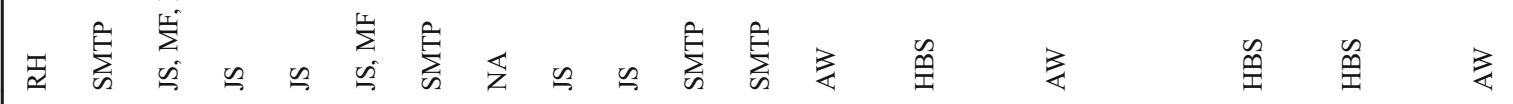

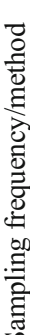

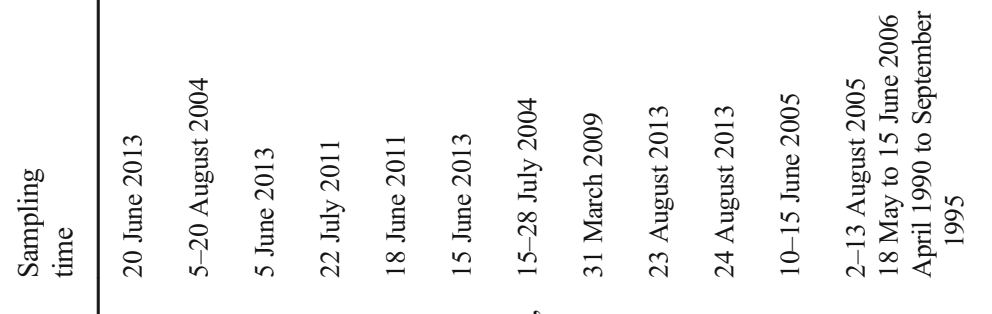

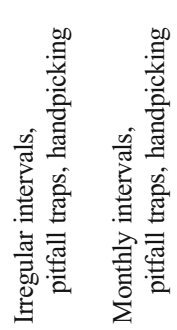

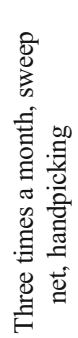

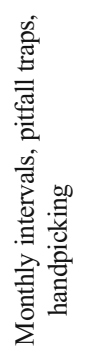

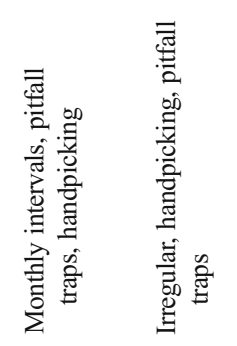
(i)

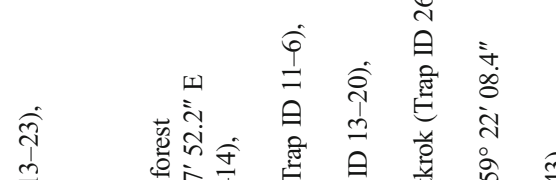

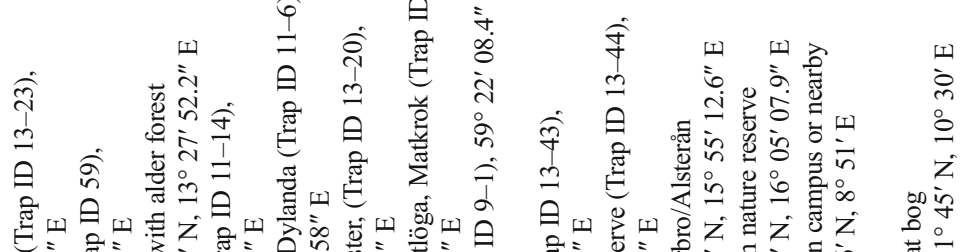

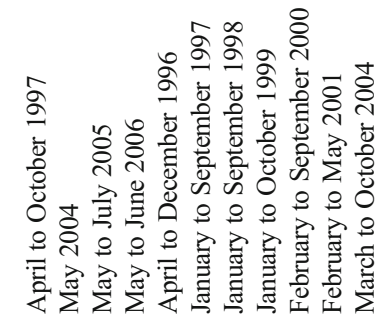

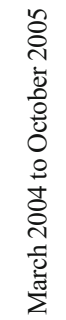

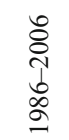

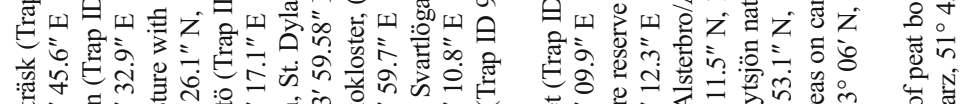

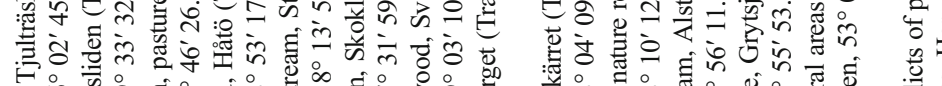

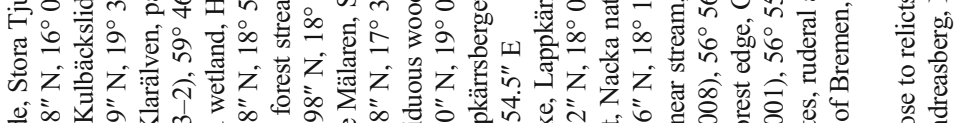

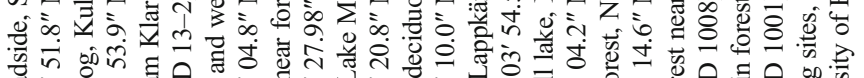

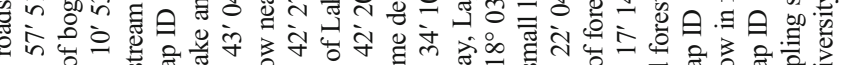

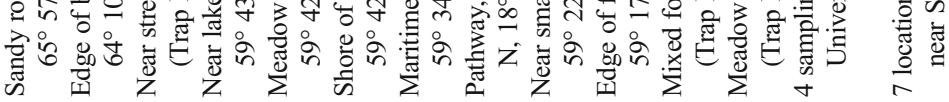

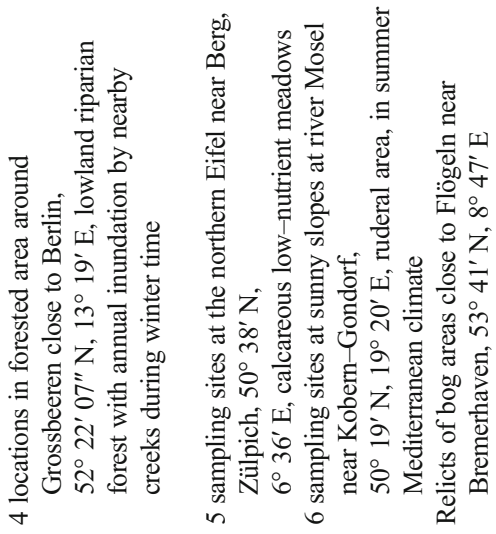

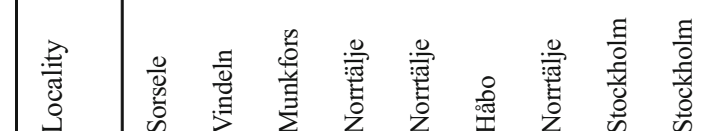

สั้ 


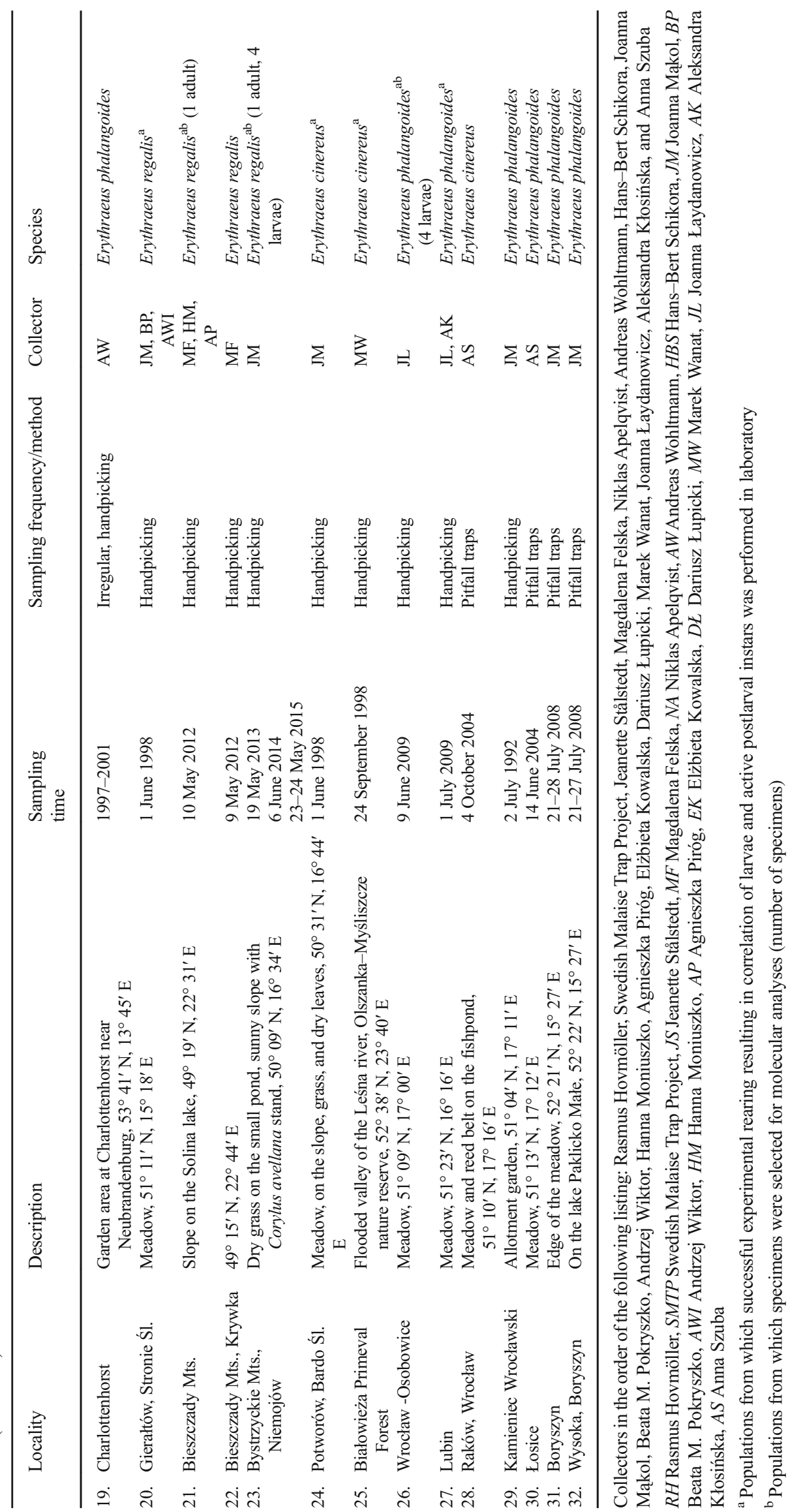




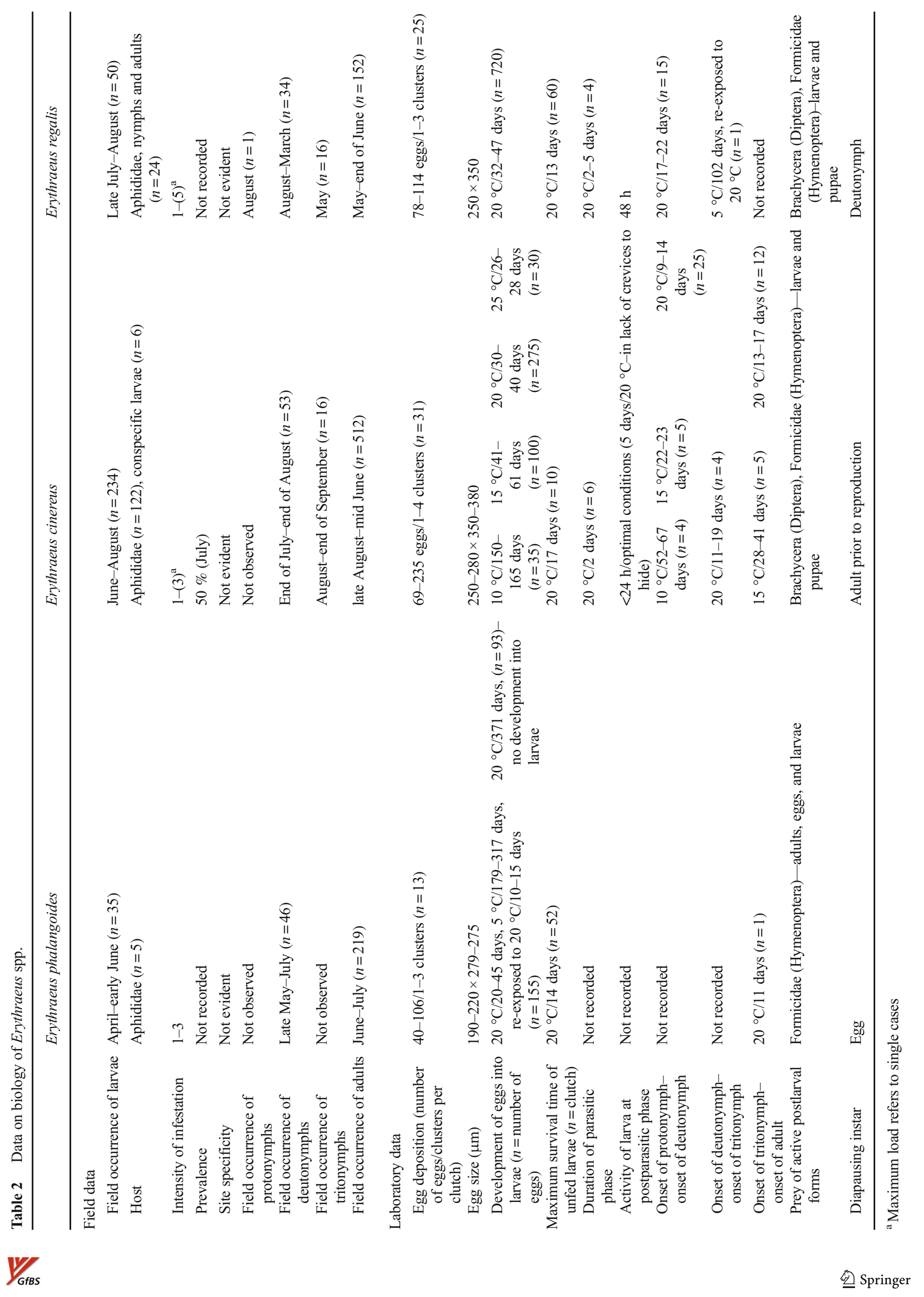


on localities, sampling time, method and frequency of sampling, collectors' name, and taxon ID, along with the data on material that underwent successful rearing and material dedicated for molecular studies, including Curteria episcopalis (C.L. Koch, 1837) selected as an outgroup, are provided in Table 1. For morphological analyses, larvae and adults selected randomly from each sample period were used. Alcoholpreserved, non-extracted specimens were cleared in potassium hydroxide or in lactic acid prior to mounting. The orcein dye was used in order to stain the exoskeletons of DNA-extracted larvae. The material was mounted on permanent slides in polyvinyl-lactophenol (material from Germany), euparal (material from Sweden), or in Faure's medium (material from Poland). Measurements and drawings were made using Nikon Eclipse 80i, Nikon Eclipse E600, or "B-2" Olympus microscope, equipped with differential interference contrast (DIC) and drawing tube. All measurements are given in micrometers $(\mu \mathrm{m})$. The total length of legs includes coxae. Terminology, abbreviations applied to morphological structures, and measurement standards follow Wohltmann et al. (2007) and Mąkol (2010), with the following modifications: $\mathrm{N}=$ non-specialized, nude seta (may have minute setules) on palps and legs and $\mathrm{B}=$ non-specialized, barbed, or setulated seta on palps and legs. Data on deutonymphs, due to their overall similarity to adults but also due to unrecognized intraspecific variation of metric and meristic data, apply only to the life instar behavior.

As the type material of E. phalangoides, E. cinereus, and $E$. regalis was unavailable for studies, we referred to original descriptions and complementary data published in an array of papers (De Geer 1778; Dugès 1834; Koch 1837; Oudemans 1910, 1929; Southcott 1961; Haitlinger 1987; Wohltmann et al. 2007), supplemented with reference material from authors' collections. Three further members of the genus (Erythraeus sp. 1, E. sp. 2, E. sp. 3) for which the separate identity was confirmed by means of molecular analyses were considered in the present study in order to strengthen the evidence on the applicability of molecular methods in separation of specific level taxa. The comprehensive characteristics of these species will constitute the subject of a separate study. DNA extractions are stored at the Swedish Museum of Natural History (NHRS), whereas voucher specimens, apart from neotypes (see: type material in systematic part of "Results and discussion"), are at the author's collections. Sequences (E. phalangoides, E. cinereus, and E. regalis) are deposited in GenBank under accession numbers KU892288KU892385.

\section{Molecular analyses}

A non-destructive method of DNA isolation was applied to specimens used for molecular analysis (Table 1), which allowed the exoskeletons to be slide mounted post-extraction (Cruickshank 2002; Dabert et al. 2008). The molecular work was carried out at the Molecular Systematics Laboratory (MSL), Swedish Museum of Natural History, Stockholm. Four legs from one side of mite's body or the whole mite, depending on the size of specimen, were subject to extraction. The extraction method followed the Cell and Tissue DNA Kit protocol of the KingFisherTM Duo (Thermo Scientific). Lysis $\left(56{ }^{\circ} \mathrm{C}\right)$ of larvae included $3-4 \mathrm{~h}$ and $15-16 \mathrm{~h}$ (overnight) for adults. The D2 region of nuclear $28 \mathrm{~S}$ rDNA (28S) was amplified using primers D2F forward 5'-AGTCGTGTTGCTTGATAGTGCAG-3' and D2R reverse 5'-TTGGTCCGTGTTTCAAGACGGG-3' (Campbell et al. 1993; Goolsby et al. 2006). PCR cycle and sequencing protocols followed Stålstedt et al. (2013).

The primers amplifying the $\mathrm{D} 2$ region of $28 \mathrm{~S}$ gave a sequence length of 582-587 bp with 116 variable characters, of which 51 were parsimony informative. Sequences with more than $10 \%$ missing data were excluded. The average nucleotide composition were $A=28 \%, G=27 \%, T=26 \%$, and $C=19 \%$.

Raw sequence data were assembled using Sequencher v. 4.10 .1 (2008). Primer sequences were removed from the beginning and end of each sequence. The $28 \mathrm{~S}$ sequences were aligned using FFT-NS-i in MAFFT v.7 (Katoh and Standley 2013) which resulted in an alignment length of $591 \mathrm{bp}$. In total, 98 samples, including C. episcopalis (C.L. Koch, 1837), taxon included as an outgroup, were used to reconstruct a gene tree with Bayesian analysis, using MrBayes v.3.2.4 (Ronquist et al. 2012). The substitution model GTR $+\Gamma$ was selected with MrModeltest v. 2.3 (Nylander 2004). The prior on branch lengths was set to an exponential distribution with a mean of 0.01 to prevent the exploration of artificially long trees (Brown et al. 2010). Markov chain Monte Carlo (MCMC) ran for 20 million generations, sampled every 500 generations and with the first $25 \%$ of samples discarded as burn-in. The standard deviation of split frequencies between runs was below 0.01 (=0.0016). The generalized mixed Yule coalescent model (GMYC) (Pons et al. 2006; Fujisawa and Barraclough 2013) was used as a method of molecular species delimitation on the single-locus gene tree. The GMYC analysis requires an ultrametric tree which was inferred with a clock model in BEAST v.2.1.3 (Bouckaert et al. 2014). Duplicate haplotypes were removed from the matrix using DNAcollapser (Villesen 2007) since identical sequences can cause problems with the GMYC model (Fujisawa and Barraclough 2013). The outgroup was excluded as the clock model roots the tree. The analysis contained 45 haplotypes and the settings were GTR $+\Gamma$, strict clock, coalescent 
Fig. 1 Majority-rule consensus from the non-clock Bayesian phylogenetic analysis of $28 \mathrm{~S}$ from Erythraeus larvae and postlarval instars sampled in the field.

Numbers above branches denote posterior probability values. The clusters of Erythraeus cinereus, E. regalis, $E$. sp. 1 , and $E$. sp. 2 have both larvae (gray) and adults (black) included. Curteria episcopalis was used as outgroup to root the tree

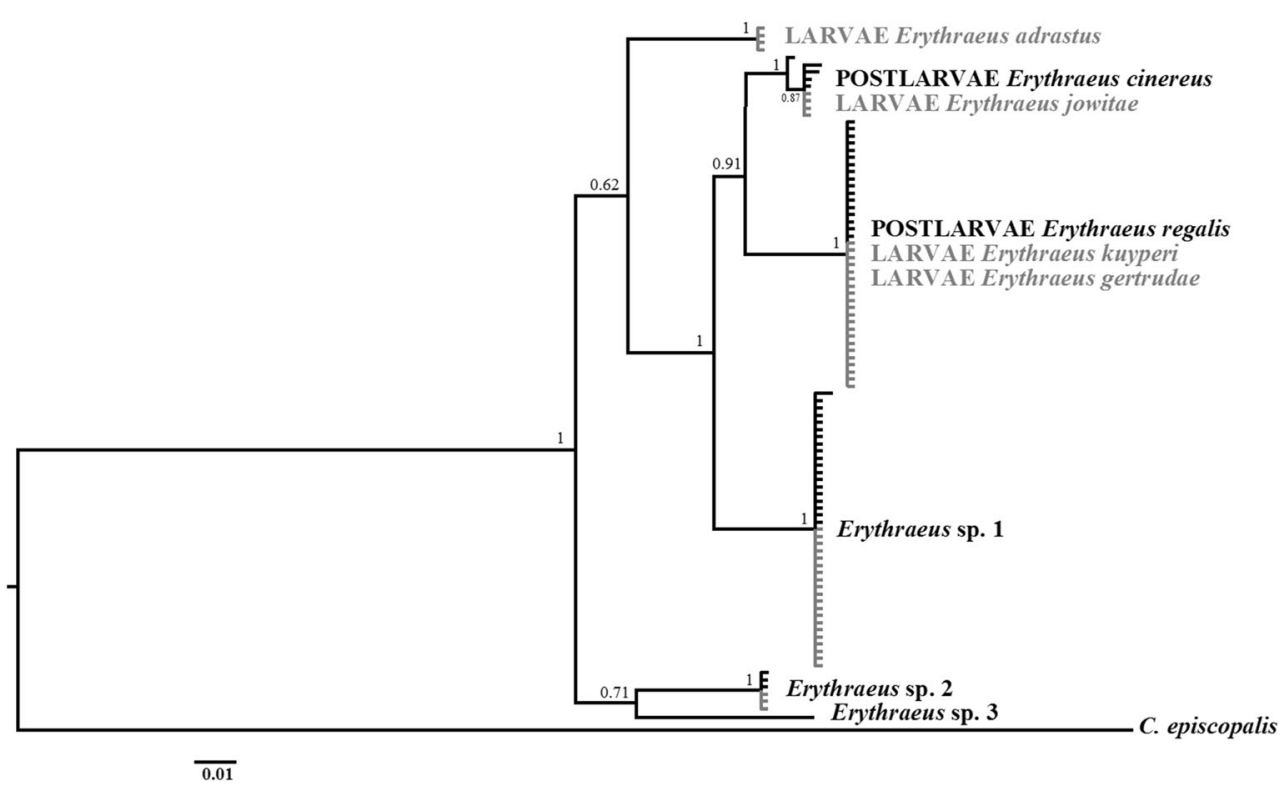

constant population tree prior, and 20 million generations (MCMC) with $25 \%$ burn-in. The GMYC analysis was performed in $\mathrm{R}$ version 3.1 .3 with the "splits" package (Ezard et al. 2014; R Core Team 2015). Nucleotide composition statistics, genetic intra- and interspecific distances (Kimura 1980), and parsimony informative characters were obtained using MEGA v.6.06 (Tamura et al. 2013).

\section{Experimental rearing}

Experimental rearing aimed at obtaining larvae from field-collected females and recognition of the diapausing instar of particular species. Live specimens were kept in laboratory in polystyrene boxes $(25 \times 25 \times 20 \mathrm{~mm})$ (material from Germany) or glass vials $(24 \times 34 \mathrm{~mm})$ covered with semi-transparent lid (material from Poland) and filled to ca $2 / 3$ with charcoaled Plaster-ofParis. The material was kept at controlled temperature $\left(20{ }^{\circ} \mathrm{C}, \pm 1{ }^{\circ} \mathrm{C}\right.$ tolerance) and light $(12 \mathrm{~h}$ dark, $12 \mathrm{~h}$ light) in environmental chambers. In case of successful development of eggs into larvae, the recorded rearing success was $>90 \%$. When development stopped at a certain instar, specimens were exposed to $5{ }^{\circ} \mathrm{C}$ for about 90 days and subsequently re-exposed to $20{ }^{\circ} \mathrm{C}$ in order to imitate winter conditions and to break diapause. Saturated air humidity and humidity of the substratum (indicated by changes in color of charcoaled Plaster-of-Paris) were attained by the addition of water to the vial. Test on the influence of humidity followed
Fig. 2 Ultrametric clock tree from Beast showing the maximum likelihood solution of the generalized mixed Yule coalescent model (GMYC). Red lines (thinner lines on the right side of the graph) indicate within-species branches, and black lines (thicker lines on the left side of the graph) represent between-species branches as inferred by the GMYC model

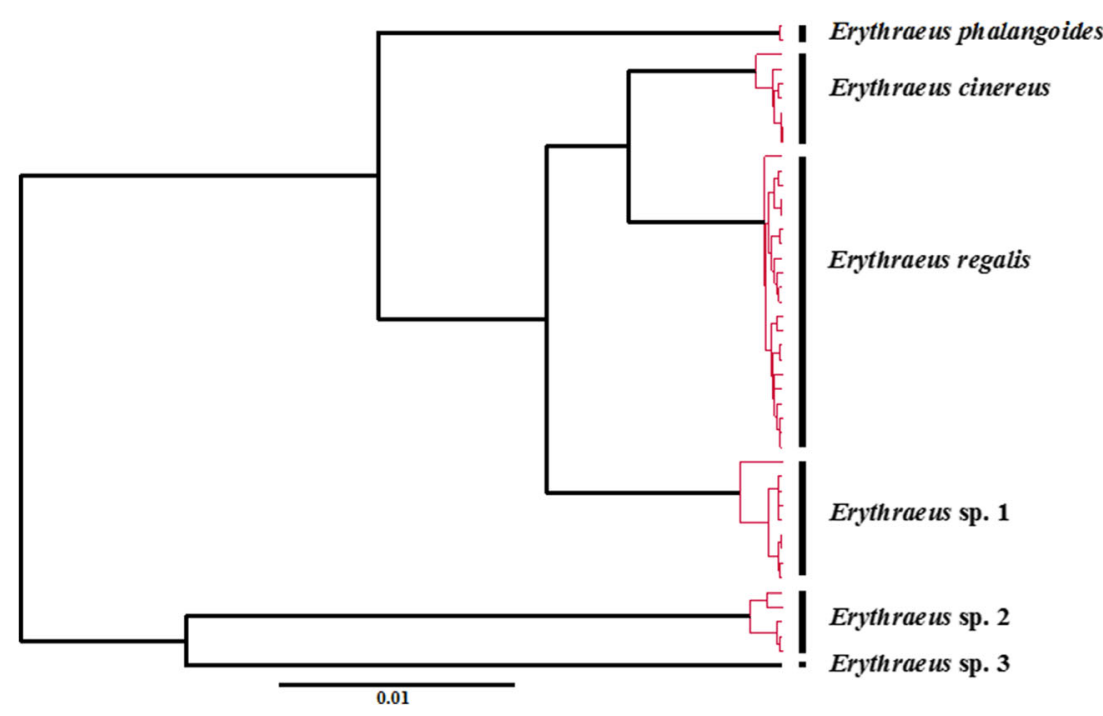


Fig. 3 Erythraeus phalangoides, adult. a Palp, medial view. b Crista metopica and eyes. c Dorsal opisthosomal setae. d Serratala on genu I. e Serratala on genu IV. f Diversity of serratalae on telofemora, genua, and tibiae of legs I-IV
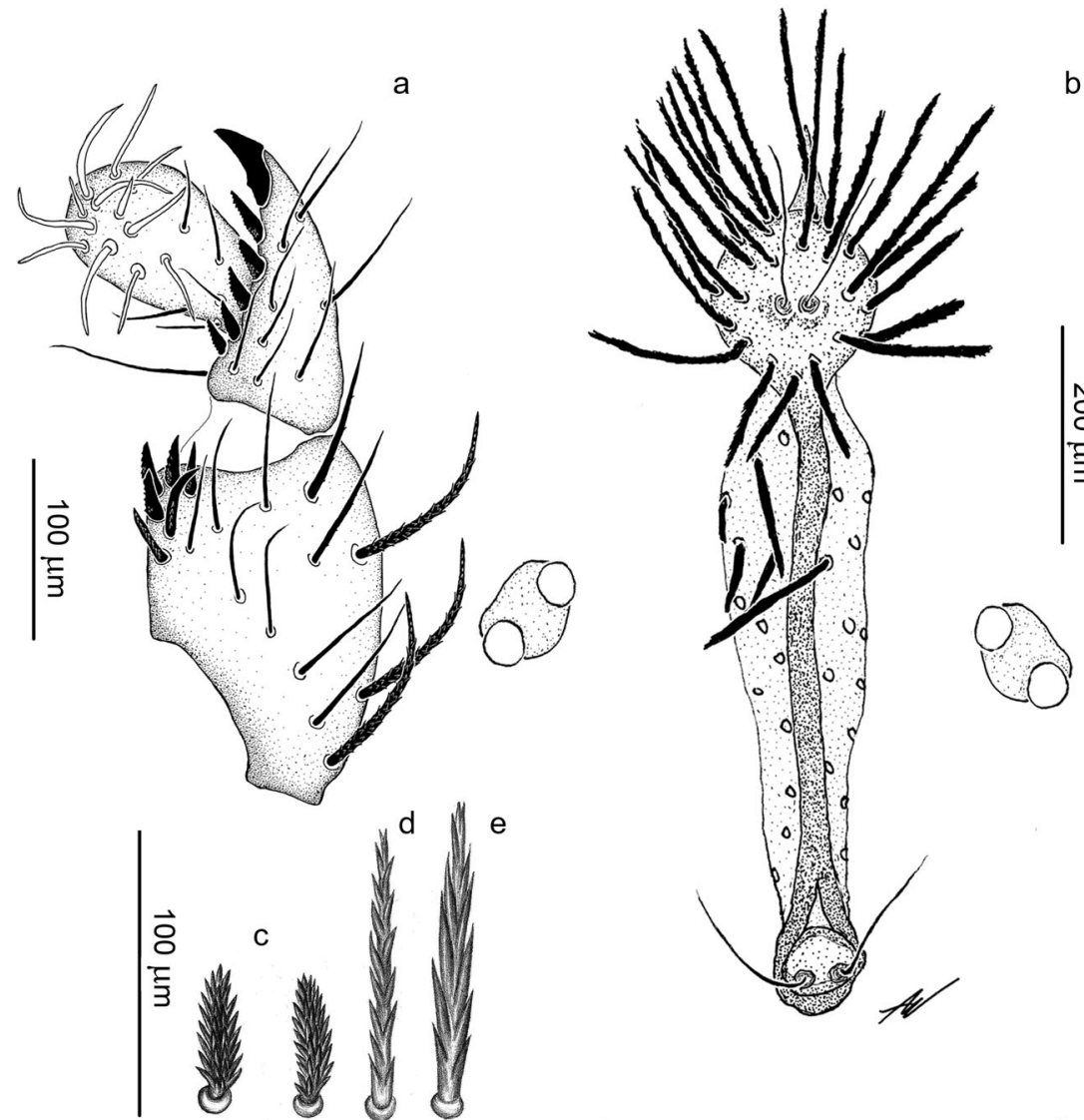

b
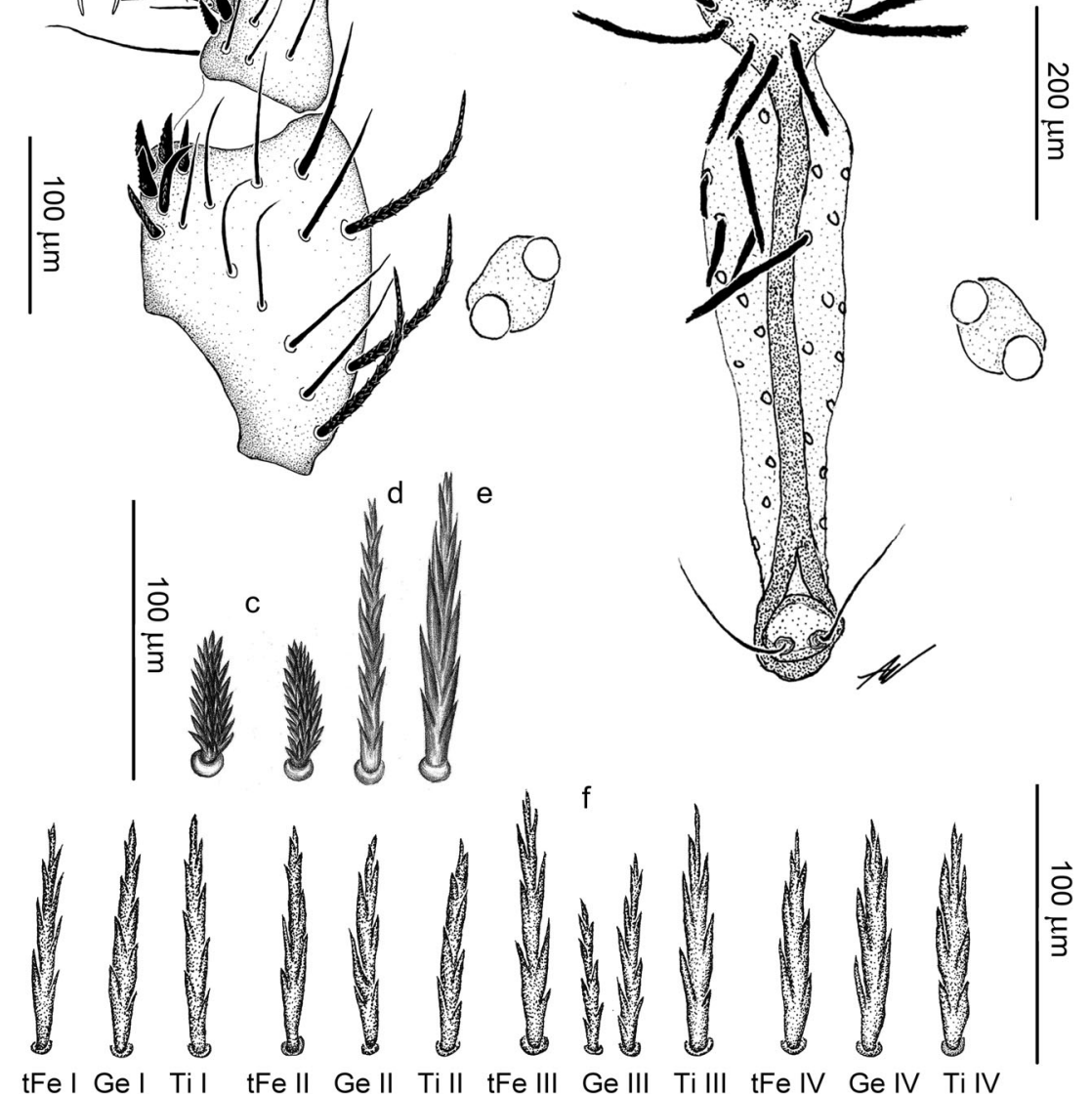

tFe I Gel Til
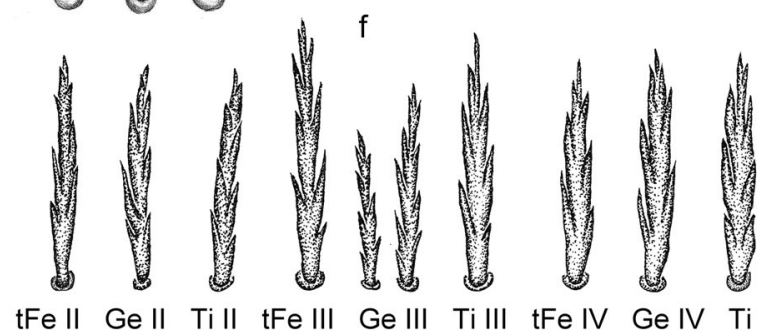

$\frac{\overrightarrow{8}}{3}$

procedures described in Wohltmann (1998). Aphididae were offered as hosts to all three Erythraeus species, while larvae of $E$. cinereus were also given the immature forms of Formicidae as well as deutonymphs and adults of Miridae. Active postlarval forms of E. cinereus and $E$. regalis were offered larvae and pupae of Brachycera (Diptera) and Formicidae (Hymenoptera) as prey.

\section{Results and discussion}

\section{Field data}

Erythraeus spp. was sampled at various locations in Sweden, Poland, and Germany (Table 1). Seasonal abundance of instars (Table 2) did not differ within a particular species sampled at various localities. Postlarval mobile instars were active on soil surface and in the litter layer. Larvae were collected either as free-living, during host search, or attached to aphid host during parasitic phase (Table 2). Only few of the immobile instars were collected in crevices. Edaphic occurrence as reported for other Parasitengona (Wohltmann 2000 and references therein) was not observed in any of the Erythraeus spp. In case of syntopic occurrence of Erythraeus sp. (10\% of studied cases - see Table 1), species usually differed in the annual abundance of instars. Data on habitat preferences and details concerning life history patterns of Erythraeus spp. are provided in systematic part of "Results and discussion" and in Tables 1 and 2. Patterns concerning phenology and biology of Erythraeus spp., observed during present study, confirm earlier reports on European members of the genus (Beron 1982; Wohltmann 2000, 2001) and fit also general data provided by Southcott $(1961,1988)$. 


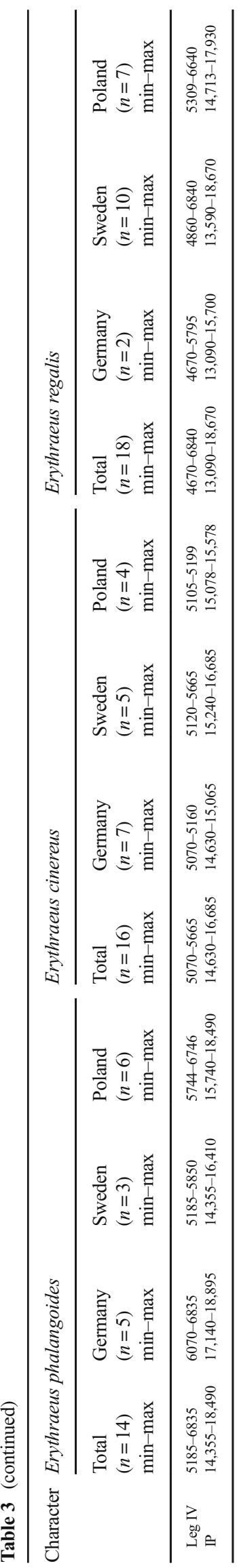

\section{Molecular data}

The gene tree from the Bayesian analysis grouped the sequences into five distinct clusters and one singleton (Fig. 1). Four clusters contained sequences from both larvae and adults $(n=87)$ (Fig. 1). All clusters had strong support ( $>0.95$ posterior probability). The GMYC model delimited six to nine entities within a 2 $\log$ likelihood unit confidence interval. The maximum likelihood solution was six entities and had a significantly better fit than the null model of a single species $(\log \mathrm{L}=400.5$ versus $383.4, d f=2, p$ value $=0.0008)$. The six separate units matched the five distinct clusters and the one singleton observed in the non-clock analysis (Figs. 1 and 2). Larvae identified as Erythraeus kuyperi and Erythraeus gertrudae was inferred to be conspecific with adults identified as E. regalis. Larvae of Erythraeus jowitae were inferred to be conspecific with adults identified as E. cinereus. Species-level taxonomic identification of specimens used for the molecular analyses was unambiguous for E. cinereus and E. regalis, whereas $E$. sp. 1 and sp. 2 require further taxonomic study. E. phalangoides (studied with larvae identified as Erythraeus adrastus) and E. sp. 3 were represented by one instar only (larvae and nymph, respectively); thus, no DNA-based life history form linkage could be inferred for these. The genetic variation within the GMYC-delimited species was very low $(0-0.5 \%)$. The genetic divergence between clusters was much larger,

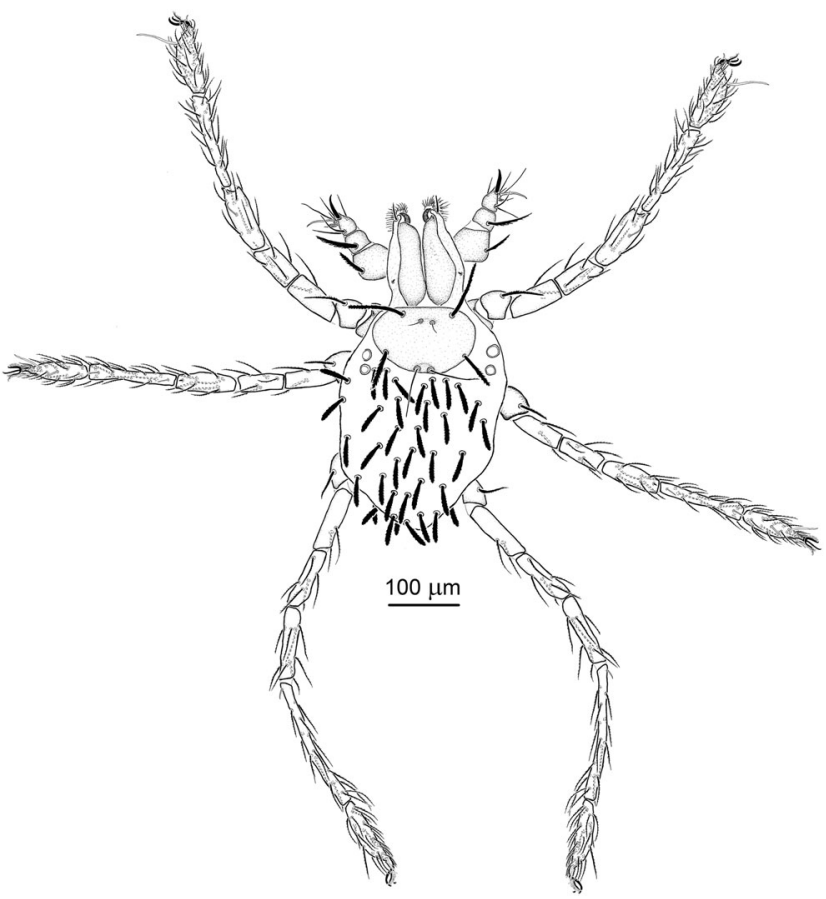

Fig. 4 Erythraeus phalangoides, larva. Habitus 
Fig. 5 Erythraeus phalangoides, larva. a Gnathosoma (and scutum), dorsal view. b Odontus. c Gnathosoma, ventral view. d Palp tarsus

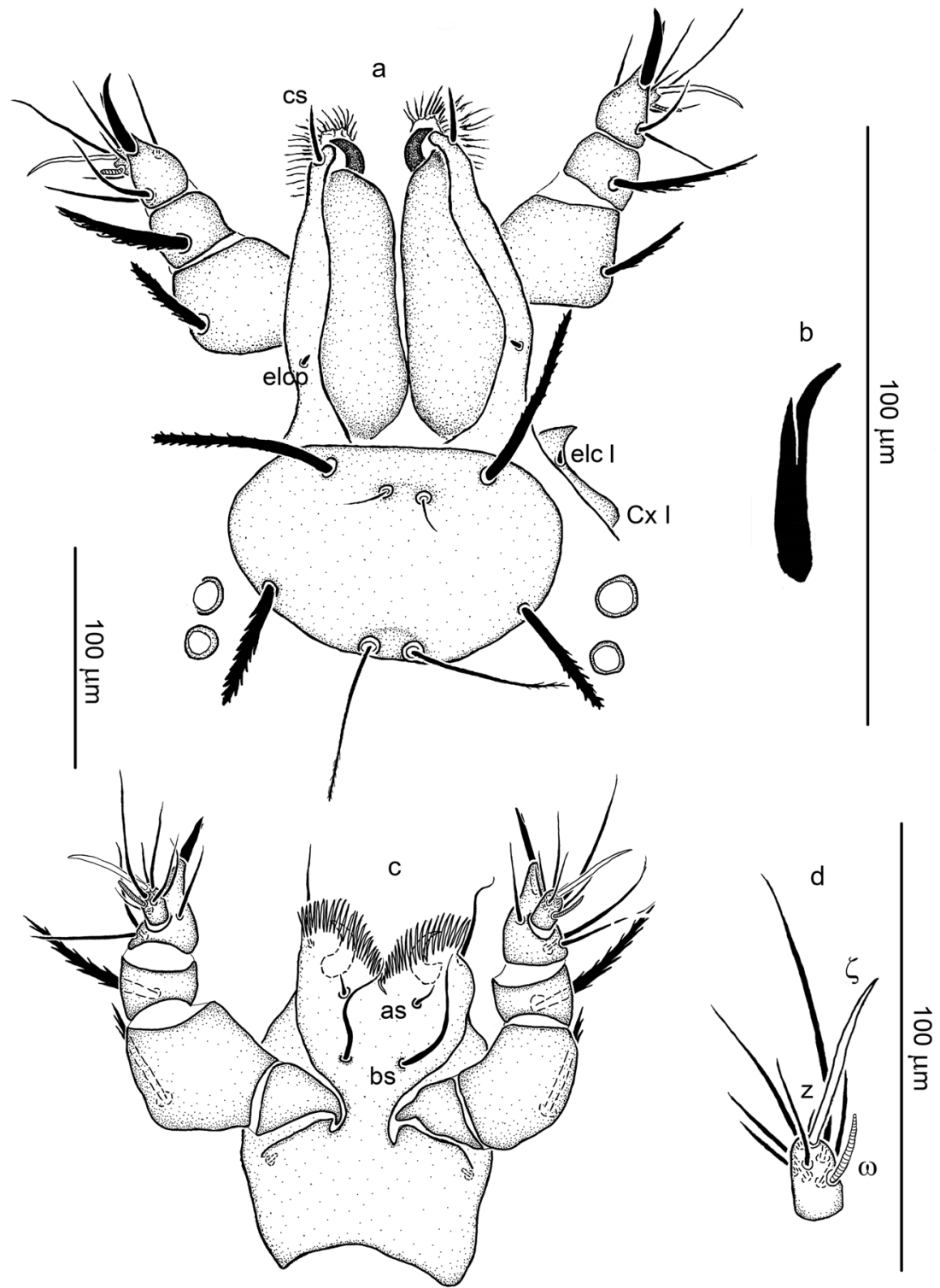

between 2.8 and $5.5 \%$. E. cinereus was separated from E. regalis, E. phalangoides and from Erythraeus sp. 1 with $2.8 \%$. A genetic distance of $4.5 \%$ separated E. cinereus from E. sp. 2 and $5.5 \%$-from E. sp. 3 . E. regalis and E. sp. 1 were separated by $3.7 \%$. The outgroup C. episcopalis was separated from the ingroup with $20 \%$.

The GMYC model of molecular species delimitation analytically confirmed the visual intuition of clusters from the Bayesian analysis as separate species (Fig. 2). The genetic distances between larvae and adults here inferred to be conspecific were also very low $(0-0.5 \%)$. In contrast, the lowest interspecific distance was $2.8 \%$. In comparison to the mitochondrial barcoding gene COI, nuclear D2 region of $28 \mathrm{~S}$ is a more conservative gene region and is expected to show less variation (Stålstedt et al. 2013). The inter-cluster distances are therefore too high to reflect within-species variation. Levels of D2 28S differentiation between species were lower than observed in aquatic Parasitengona of the genera Hygrobates C.L. Koch, 1837, Piona C.L. Koch, 1842, and Unionicola Haldeman, 1842 (Martin et al. 2010; Stålstedt et al. 2013) but similar to those recorded for the majority of currently recognized congeneric species, including other actinotrichid mites (Skoracka and Dabert 2010; Skoracka et al. 2013). The intraspecific variation was within the range found for other Parasitengona species (Stålstedt et al. 2013).

\section{Rearing data}

Successful laboratory rearing was carried out for each of the three Erythraeus spp. sampled in the field (Tables 1 and 2). Eggs were ovoid and orange just after deposition but turned 
Fig. 6 Erythraeus phalangoides, larva. a Gnathosoma and idiosoma, dorsal view. b Dorsal opisthosomal setae. c Gnathosoma and idiosoma, ventral view. d Seta $p s$
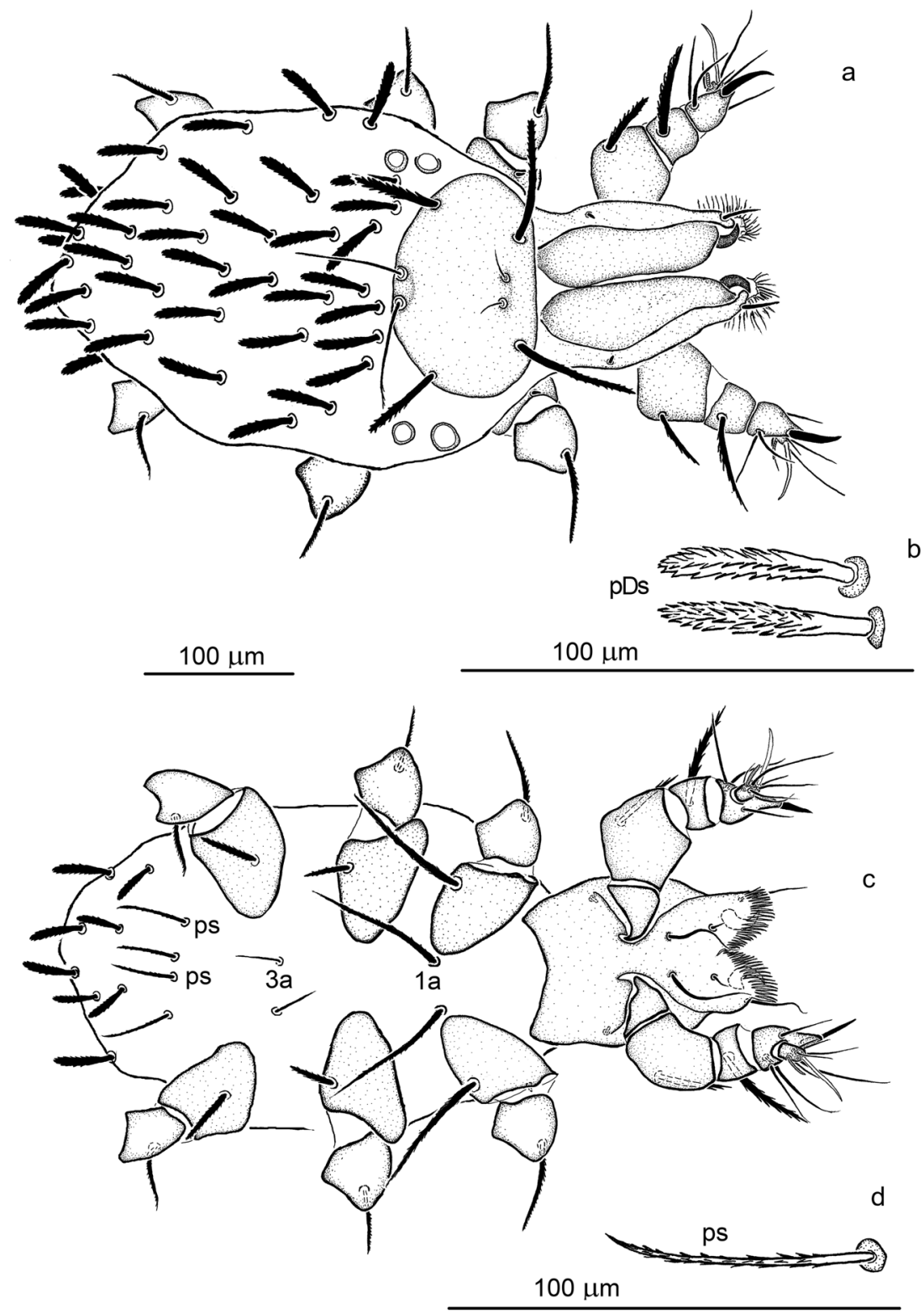

black within $24 \mathrm{~h}$. Larvae hatched about a month later in $E$. cinereus and E. regalis, while eggs of E. phalangoides underwent obligatory diapause and developed into prelarvae and subsequently into larvae only when kept at $5{ }^{\circ} \mathrm{C}$ for the period amounting to about 6-10 months, followed by reexposure to $20^{\circ} \mathrm{C}$. After hatching, larvae displayed positive phototactic response. Unfed larvae survived without hosts for a few days only (Table 2). When kept together with aphids, larvae readily started parasitism. Fully engorged larvae moved comparably fast but did not display positive phototactic response. Instead, they tried to hide in crevices, where they became motionless and entered the calyptostatic protonymph. Deutonymphs and adults were fed with larvae and pupae of brachyceran flies and ants. In E. regalis, the deutonymphs displayed obligatory diapause and continued development into subsequent instars only after chilling at $5{ }^{\circ} \mathrm{C}$ for about 100 days. For E. cinereus, the obligatory diapause was recorded in adults, before the onset of reproduction. Additional laboratory data on E. phalangoides, E. cinereus, and E. regalis are provided under respective species description and in Table 2. Data on biology and life history patterns confirm earlier reports by Wendt (1996) and Wohltmann (2000, 2001), applying to Erythraeus spp.

\section{Systematic part}

Two-way linkage of larvae and postlarval forms-DNA analysis of field-collected specimens and/or laboratory rearing of 
Fig. 7 Erythraeus phalangoides, larva. a Leg I. b Leg II. c Leg III. d Tarsus I. e Tarsus II. f Tarsus III (d-f, only specialized setae shown)

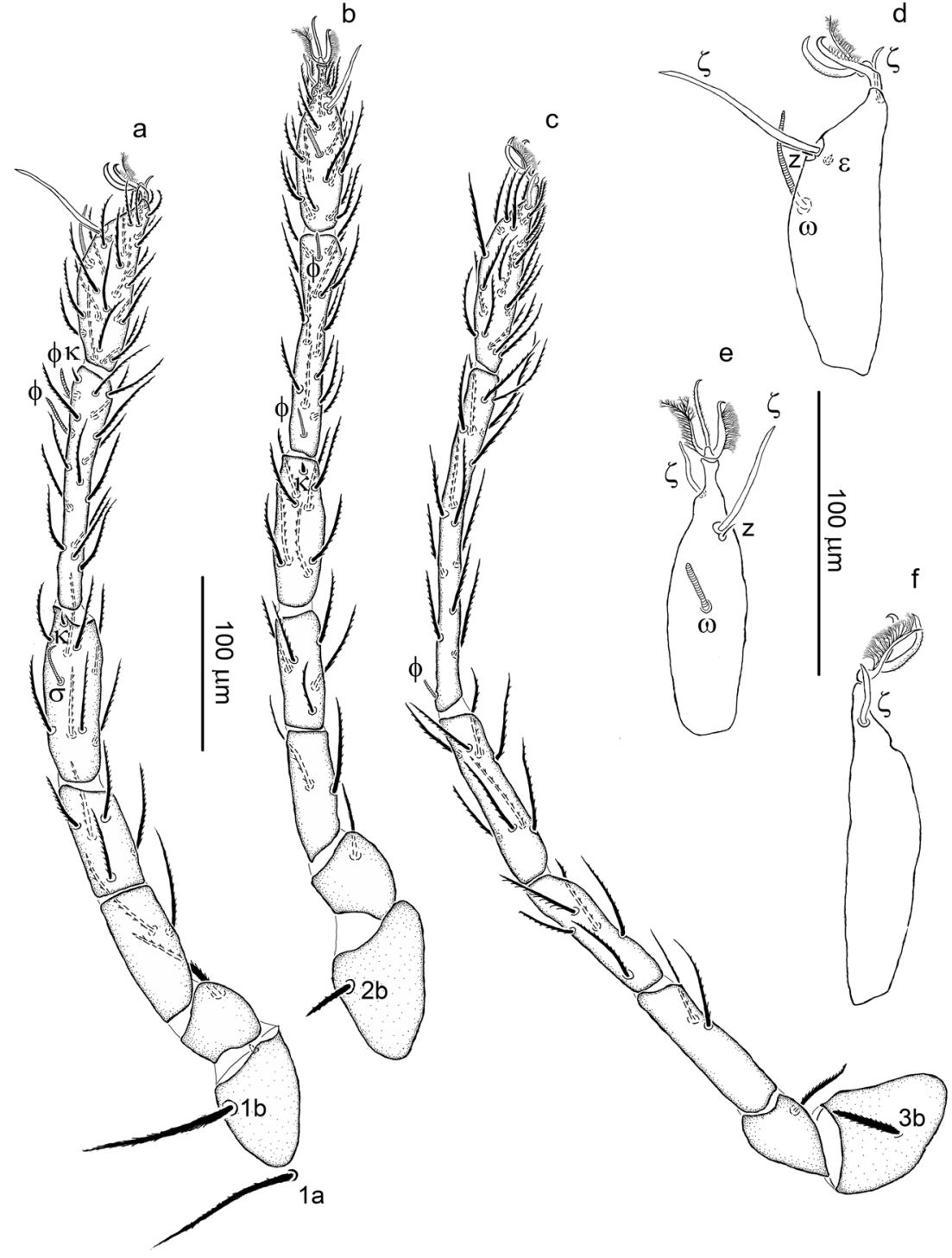

larvae from ovigerous females - resulted in the following synonyms: E. phalangoides (De Geer, 1778) [= E. adrastus (Southcott, 1961), syn. nov.], E. cinereus (Dugès, 1834) [= E. jowitae Haitlinger, 1987, syn. nov.], and E. regalis (C.L. Koch, 1837) [= E. kuyperi (Oudemans, 1910), syn. nov., = E. gertrudae Haitlinger, 1987, syn. nov.]. The following redescriptions include variation of morphological and life history traits between different populations (Sweden, Poland, and Germany) of the particular species. In order to maintain the stability of nomenclature, we are of the opinion that the names of species described in the eighteenth and nineteenth century with an insufficient set of characters in the original descriptions should nevertheless be retained due to their extensive usage and, since they do not contradict the present knowledge of the taxa in question, be supported by much more extended characteristics.

Erythraeidae Robineau-Desvoidy, 1828

Erythraeinae Robineau-Desvoidy, 1828
Other subfamilies: Abrolophinae Witte, 1995, Balaustiinae Grandjean, 1947, Callidosomatinae Southcott, 1957, Leptinae Billberg, 1820, Myrmicotrombiinae Southcott, 1957, Phanolophinae Southcott, 1946a

Type genus: Erythraeus Latreille, 1806

Erythraeus Latreille, 1806

For synonymy, see Southcott (1961) and Beron (2008).

\section{Diagnosis}

Adult (after Southcott (1961), with modifications, after Wohltmann et al. (2007)): Crista metopica set on indistinct scutum, with two sensillary areas set apart, close to extreme parts of crista; each sensillary area with a pair of trichobothria; two pairs of eyes, each pair inserted in ocular plate; genital plates located at the level of coxae III-IV, distinctly larger than anal sclerites; on medial 


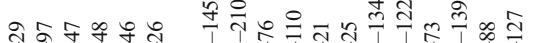

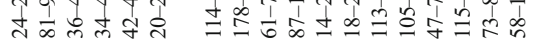

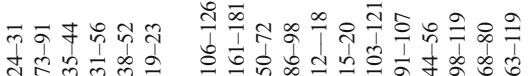

ஃ

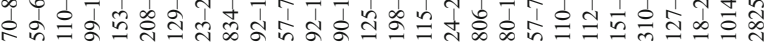

욱

鲜

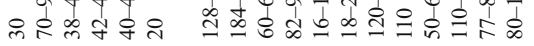

๙ิ

$\stackrel{\text { ॥ }}{\Xi}$

㔄罗

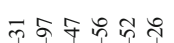

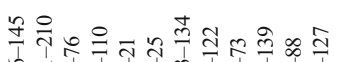

규용

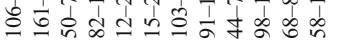

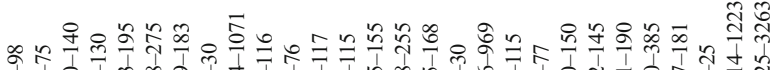

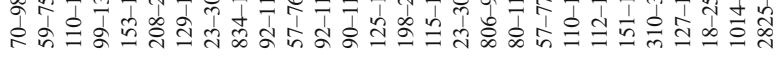

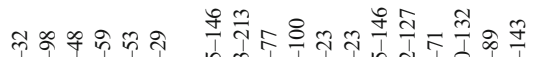

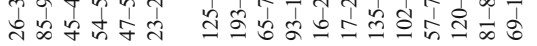

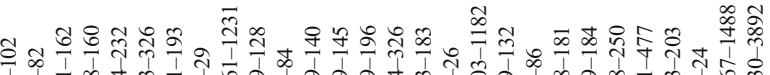

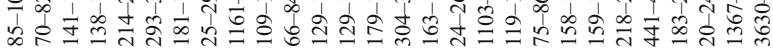

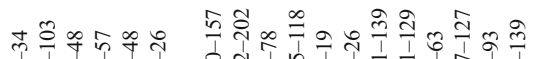

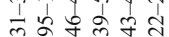

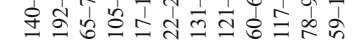

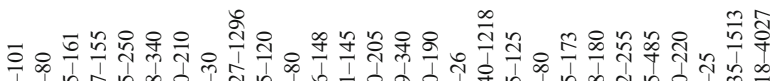

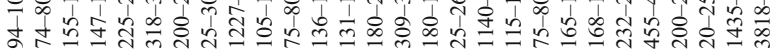

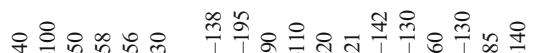

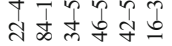

웅ㅇํ

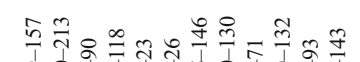

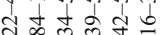

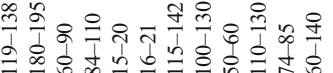

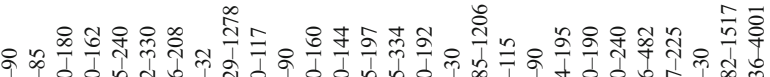

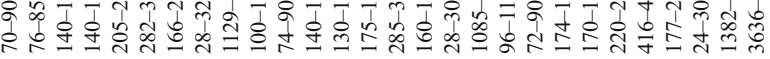
กิ $\stackrel{\text { I }}{\Xi}$

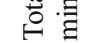

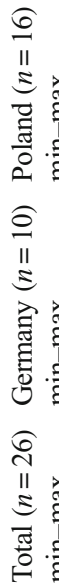

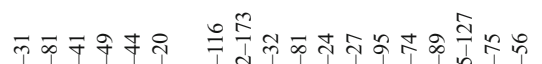

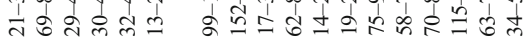

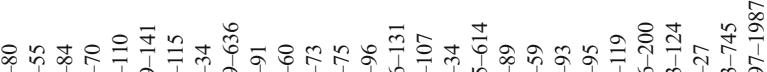

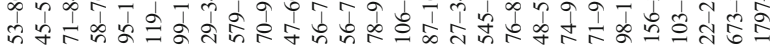

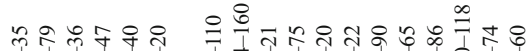

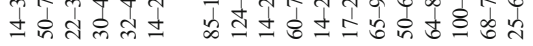

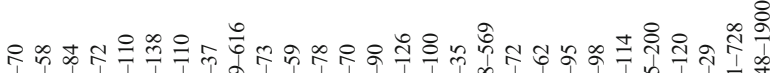

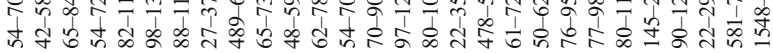

m

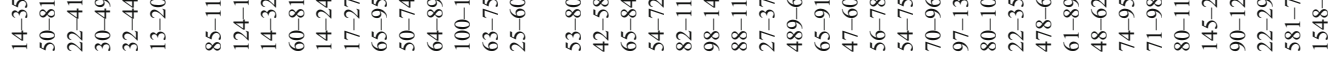

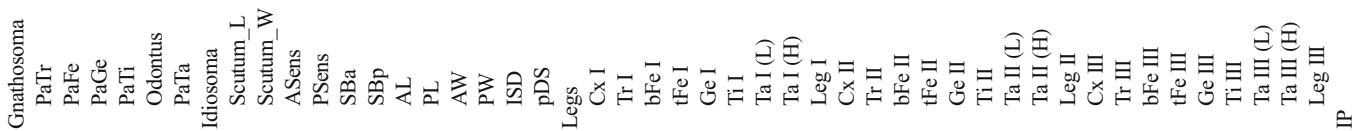




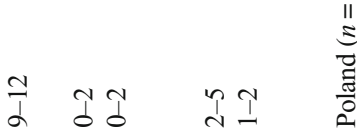

年先

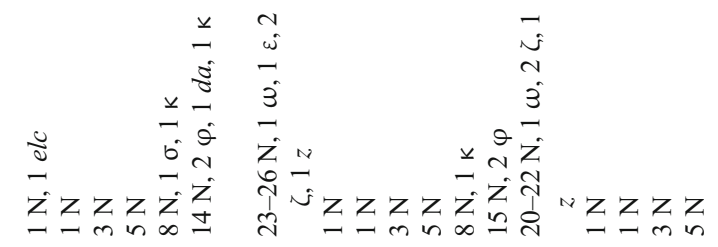

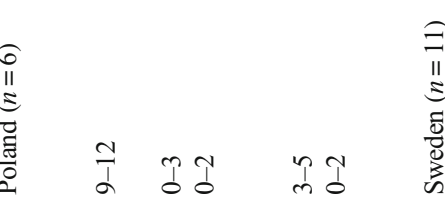

全

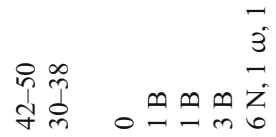

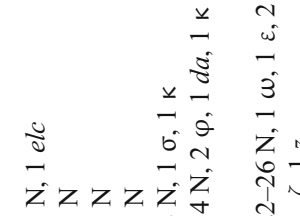

is is

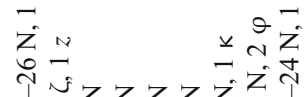

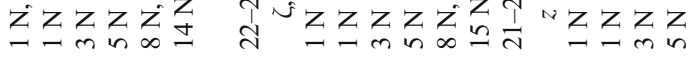

อ

$\stackrel{\widehat{I}}{\stackrel{1}{\Xi}}$

$\stackrel{\circ}{\infty}$ I I $T$ i

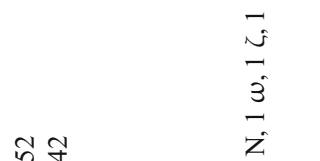

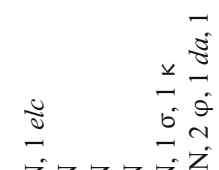

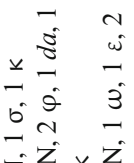

is

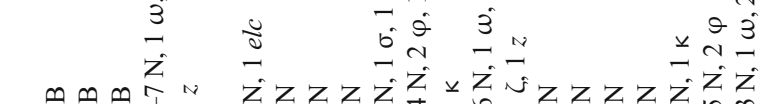

郘

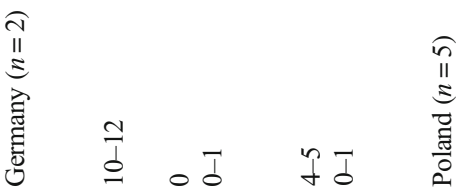

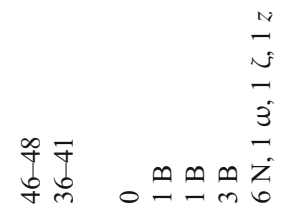

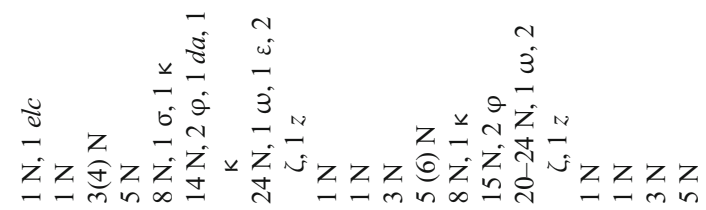

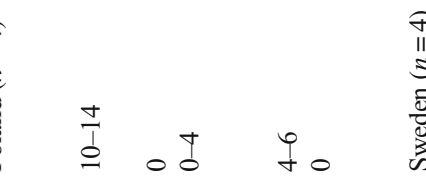

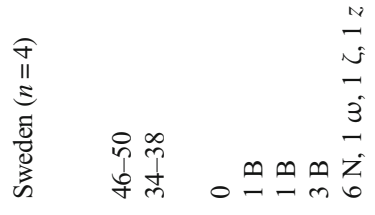

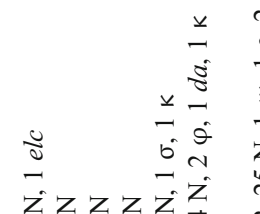

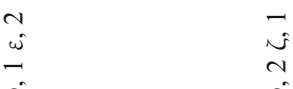

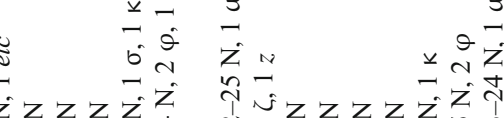

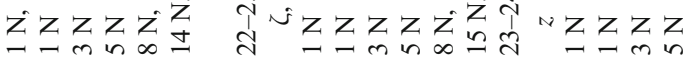

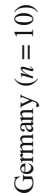

至京

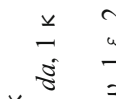

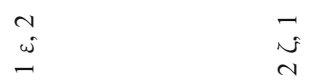

in

$\frac{1}{1}$ o $\frac{0}{0}$ 站

$\because \quad \frac{\square}{0} \stackrel{0}{0}$

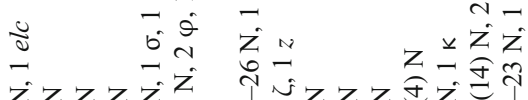

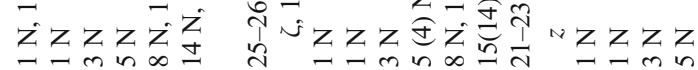

@

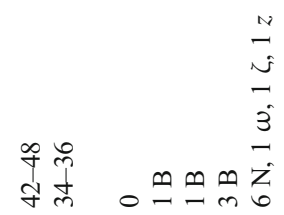

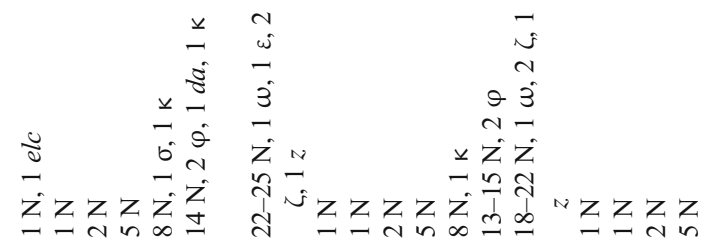

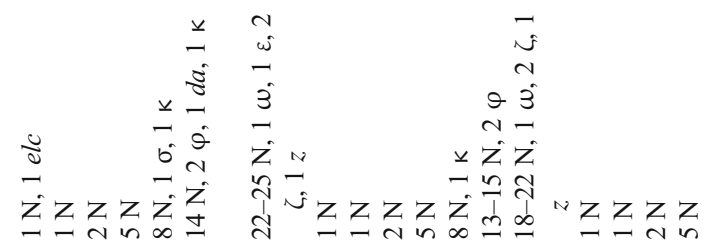

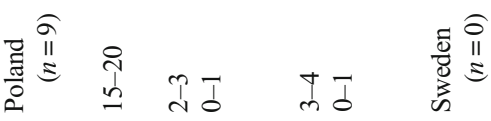

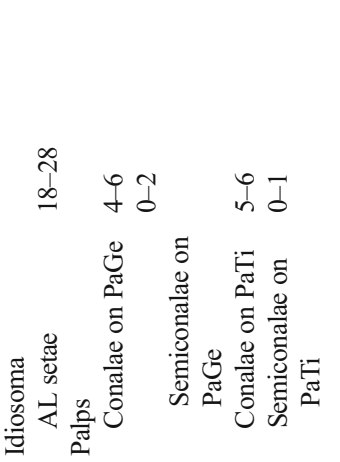

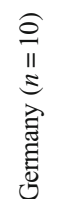

$\stackrel{N}{N}$

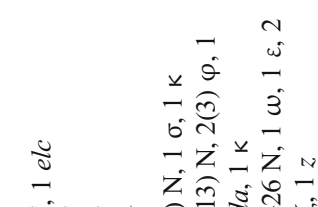

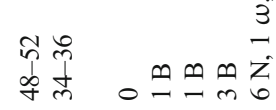

落z

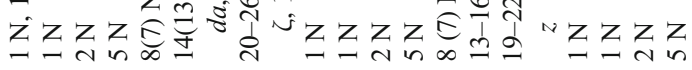

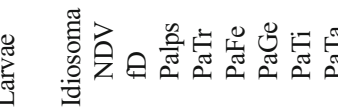

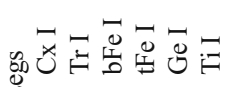

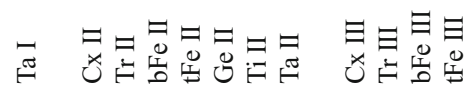


face of palp tibia and sometimes also on palp genu, ventrally, a row of cone-like, serrate setae (conalae), accompanied by more slender semi-conalae; leg segmentation formula 7-7-7-7; legs with modified stout setaeserratalae

Deutonymph: Similar to adult but smaller and with sparser setation; urvulva (external genital plate of deutonymph, after Southcott (1961)) of comparable size to anal sclerite or smaller; conalae and semi-conalae of palp genu and palp tibia, if present, more weakly developed (both, with respect to the number and size)

Larva (after Wohltmann et al. (2007); Southcott (1988)): Scutum oval or trapezoidal in outline, with two pairs of trichobothria and two pairs of non-sensillary setae; eyes, each composed of double lens, placed laterally to scutum; leg segmentation formula 7-7-7; $\mathrm{f}_{\mathrm{n}} \mathrm{Cx}=1-1-1, \mathrm{f}_{\mathrm{n}} \mathrm{Tr}=1-1-1$, and $\mathrm{f}_{\mathrm{n}} \mathrm{bFe}=2-2-2$ or $3-3-3$

Remarks: Southcott (1961), in the generic diagnosis of Erythraeus, listed the lack of serratalae on legs, contrary to their presence in the Australian Erythroides Southcott, 1946b; for the latter genus, the tentative, separate generic affiliation can be confirmed by the lack of conalae in active postlarval forms and presence of three pairs of scutal setae in larvae

Type species: Acarus phalangoides De Geer, 1778

Distribution: Worldwide

Erythraeus phalangoides (De Geer, 1778)

Acarus phalangoides De Geer, 1778

Bochartia adrastus Southcott, 1961, syn. nov.

Type material: Neotype (NHRS-ACAR 000000095), male (for the place of origin, see Table 1, locality 5, collection date: 18 June 2011), mounted on one slide, is deposited in the Swedish Museum of Natural History, Stockholm, Sweden

Diagnosis (data for neotype given in parentheses)

Adult: Palp genu: 2-6 (2) conalae, 0-3 (1) semi-conalae; palp tibia: 3-6 (4) conalae, 0-1 (1) semi-conalae; anterior sensillary area of crista metopica (ASA) with indistinct anterior process and with 15-30 (20) non-sensillary setae; dorsal opisthosomal setae uniform, robust, cone-like, with stout setules; serratalae moderately developed, present on all legs (see Fig. 3 for comparison)

Larva: AL not inflated basally, ASens short (14-32), $\mathrm{fD}=34-36, \mathrm{f}_{\mathrm{n}} \mathrm{bFe}=2-2-2$, Ti III $145-200$

\section{Description}

Adult: Fig. 3; metric data: Table 3; meristic data: Table 5

Color in life reddish-brown with black setae, eyes bright red

Gnathosoma: Chelicerae typical for the genus; palps with relatively sparse setation; normal, setulated setae present on palp trochanter and palp femur; palp genu with strong, serrate setae dorsally, smooth, and more slender setae laterally, two to 
six conalae and zero to three spine-like semi-conalae (i.e., setae with rough, serrated surface, not more than twice as long as conalae, pointed); palp tibia with normal, sparsely barbed setae and with three to six conalae and zero to one semiconalae; odontus hook-like; palp tarsus hemispherical, with the apical part overreaching the termination of odontus, densely covered with eupathidia and solenidia

Idiosoma: Scutum roughly limited to crista metopica; anterior process of ASA, weakly sclerotized, indistinct; posterior process of posterior sensillary area (PSA) absent; ASens and PSens covered with very tiny barbs; on ASA-15-30 setae AL; ocular plates (75-90 × 100-120), located laterally to crista, at ca half of its length; dorsal setae uniform in shape, short (22-70), cone-like, rounded at tip, covered with stout setules; ventral setae (VS) slender, covered with short setules; GOP surrounded by paired sclerites (genital plates: epivalves and centrovalves), located at the level of coxae III-IV; setae covering valves shorter than VS, slender, with delicate barbs; AOP surrounded by indistinct paired valves, and of those, the external valves more sclerotized; setae covering valves similar to those covering genital plates but shorter

Legs: Serratalae present on basifemora, telofemora, genua, and tibiae of all legs; the most stout ones occur on leg IV; other setae of normal shape; setulated setae present on all leg segments (on genua and tibiae-in minority); specialized setae distributed on $\mathrm{bFe}-\mathrm{Ta}$; tarsi I-IV terminated in paired claws, each claw covered with fimbriae

Larva: Figs. 4, 5, 6, and 7, habitus as in Fig. 4; metric data: Table 4; meristic data (including leg chaetotaxy): Table 5

Color in life light orange, with distinct yellowish rings on legs I-III
Fig. 8 Erythraeus cinereus, adult. a Palp, medial view. b Crista metopica and eyes. c Dorsal opisthosomal setae. d Serratala on genu I. e Serratala on genu IV. f Diversity of serratalae and setae of non-serratalae type on telofemora, genua, and tibiae of legs I-IV

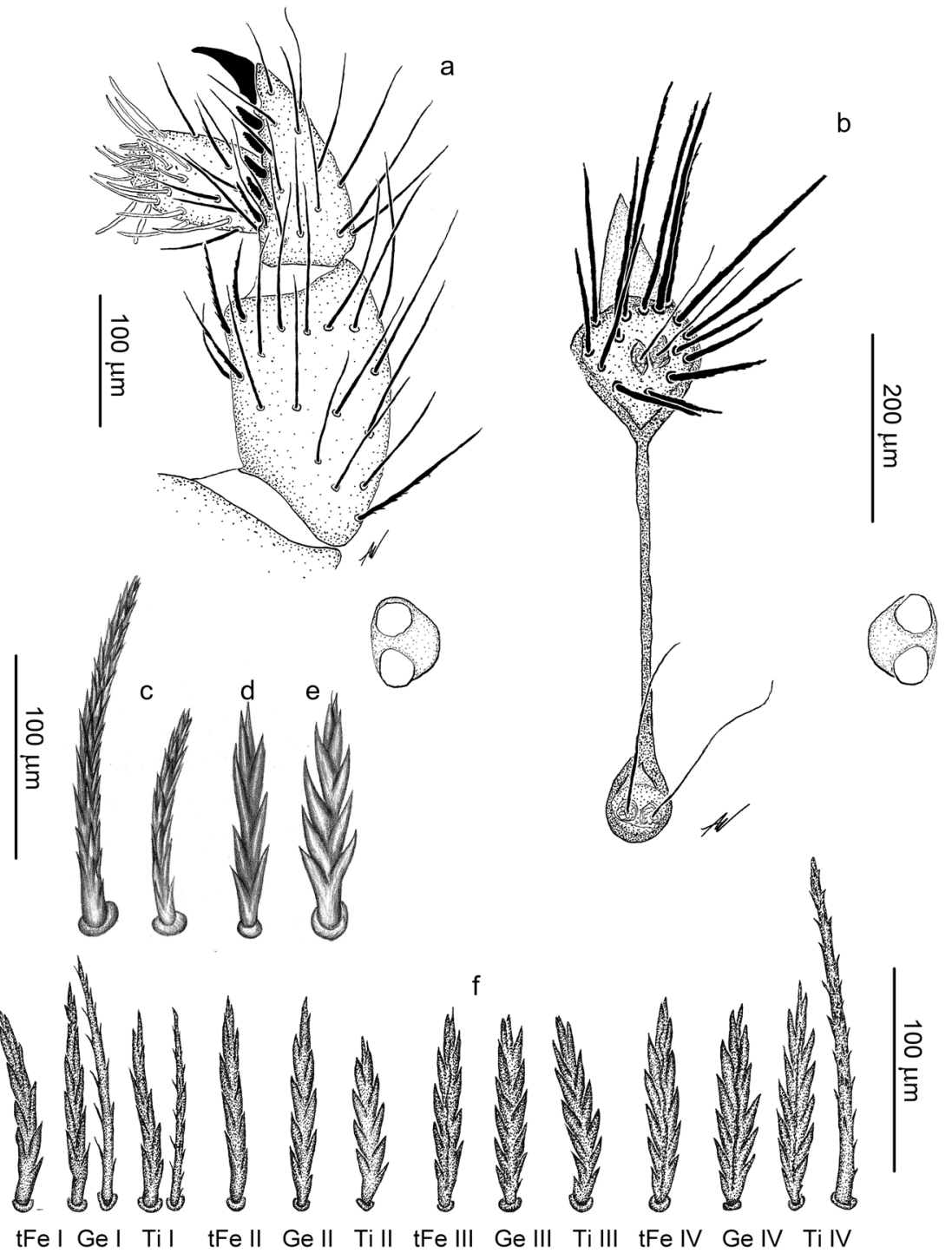


Gnathosoma (Fig. 5): Cheliceral claw, with distinct subterminal hook on the blade; a pair of smooth, pointed adoral setae (cs) (32-44), located distally; paired, clubshaped, supracoxal setae (elcp, 4-6) placed dorsally, in antero-lateral position; on ventral side of gnathosoma-a pair of smooth, pointed subcapitular (hypostomal, tritorostral) setae $(b s)(50-70)$ and, in more anterior position - a pair of spine-like oral setae (as) (10-14); pedipalp formula: 0-B-B-BBB-NNNNNN $\omega \zeta z$; palp femur and genu, each with one setulated seta dorsally, palp femoral seta (40-50) always shorter than palp genual seta (60-80); palp tibia with three setae covered with indistinct setules; odontus with dorsal, splinter-like branch, arising at half length of claw and not reaching claw termination; palp tarsus with one distinctly elongated and five shorter, smooth normal setae, one solenidion $(\omega)$ and one prominent distal eupathidium $(\zeta)$; the latter associated with tiny companion seta $(z)$
Idiosoma (Fig. 6): Scutum oval in outline; anterior border almost straight, lateral, and posterior borders rounded; AL not widened at base; AL and PL serrate, ASens much shorter than PSens; paired eyes located postero-laterally of scutum, anterior lens (10-18) slightly larger than the posterior lens (8-16); dorsal setae short (25-60), thick, serrate; NDV (total number of setae on idiosoma, excl. setae on scutum and intercoxalae) $=42-52$; coxa I with serrate seta 1b (80-100), seta 1a (71-104) located outside coxal plate I; coxa II with serrate seta $2 \mathrm{~b}(25-38)$; coxa III with serrate seta 3b (28-40); seta 3a (28-38) located outside coxa III; posterior to coxae III four pseudanal setae, $p s$ (24-55), distinctly thinner than dorsal idiosomal setae

Legs (Fig. 7): Segmentation formula: 7-7-7; solenidia on genu I and tibia I short (20-30); solenidion $(\sigma)$ on genu located about half length of the segment, solenidia $(\varphi)$ on tibia I located in distal half of the segment, distal solenidion with companala $d a$; solenidion $(\omega)$ on

Fig. 9 Erythraeus cinereus, larva. a Chelicera. b Gnathosoma (and scutum), dorsal view. c Gnathosoma, ventral view. d Palp tibia. e Palp tarsus

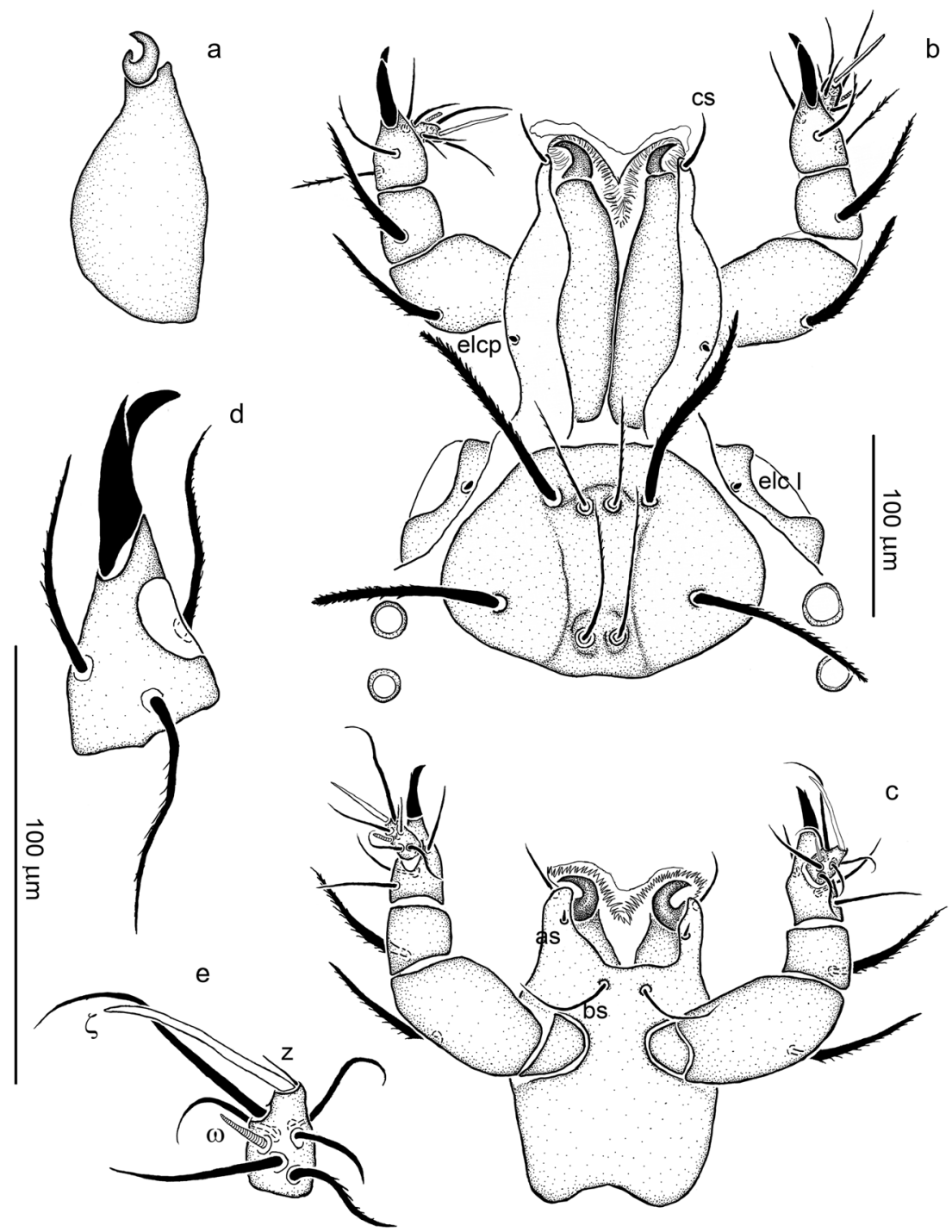


tarsus I prominent (40-45), famulus $(\varepsilon)(4-5)$ small, inconspicuous; subterminal eupathidium on tarsus I long (60-70) and with accompanying seta $z(10-20)$, "pretarsal" eupathidium shorter (25-27), without $z$; all solenidia on leg II short (15-20); solenidia on tibia II arise at proximal and distal margin of the segment, respectively; subterminal eupathidium on tarsus II long (40-50) and with companala $z(7-15)$, "pretarsal" eupathidium shorter (20-25), without $z$. Solenidion on tibia III short (15-20), located proximally, "pretarsal" eupathidium short (20-25), without $z$; median empodium of pretarsi I-III claw-like, with small lateral barbs; anterior claw with terminal hook, posterior claw without hook; both claws aliform

Distribution: Western Palaearctic

Remarks on taxonomy
Larvae of $E$. phalangoides fit the description of $E$. adrastus (Southcott, 1961). The specimens upon which Southcott (1961) based his description had been sampled in Denmark, on the sides of ant hills by Haarløv (1957), who reported the larvae to represent $E$. phalangoides. Southcott (1961) assumed that E. adrastus constitutes the larva of $E$. phalangoides; however, in the lack of correlation confirmed by rearing, he refrained from synonymization. Present laboratory rearing of $E$. phalangoides eggs, obtained from fieldcollected females, confirms the supposition of Haarløv (1957) and Southcott (1961); thus, E. adrastus should be regarded a junior synonym of $E$. phalangoides.

Biology

Field data and laboratory data are provided in Table 2. E. phalangoides is associated with a wide range of habitats, from sandy dunes close to marine
Fig. 10 Erythraeus cinereus, larva. a Gnathosoma and idiosoma, dorsal view. b Dorsal opisthosomal setae. c Gnathosoma and idiosoma, ventral view. d Seta $p s$
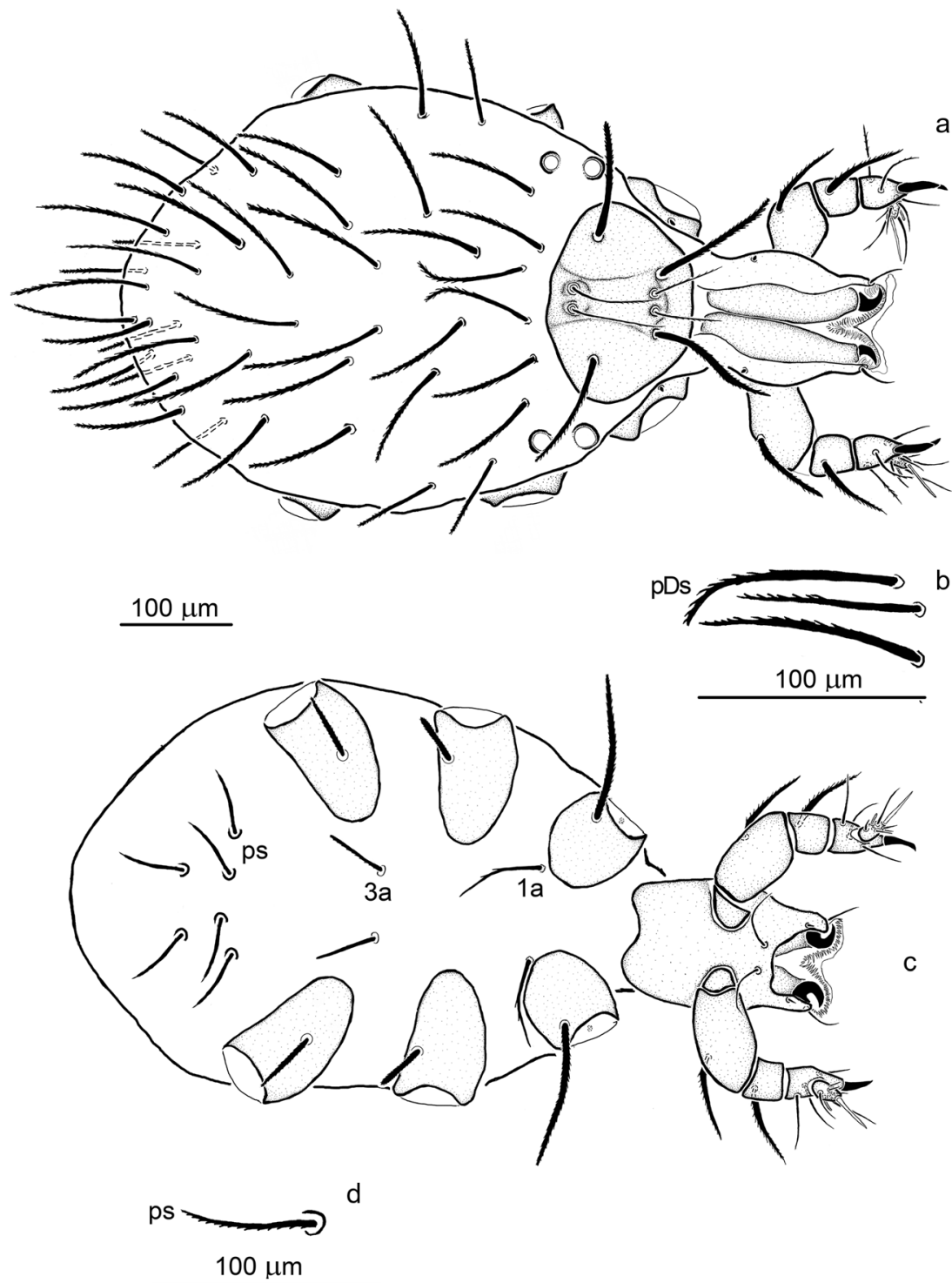
Fig. 11 Erythraeus cinereus, larva. a Leg I. b Leg II. c Leg III. d Tarsus I. e Tarsus II (d, e, only specialized setae shown)
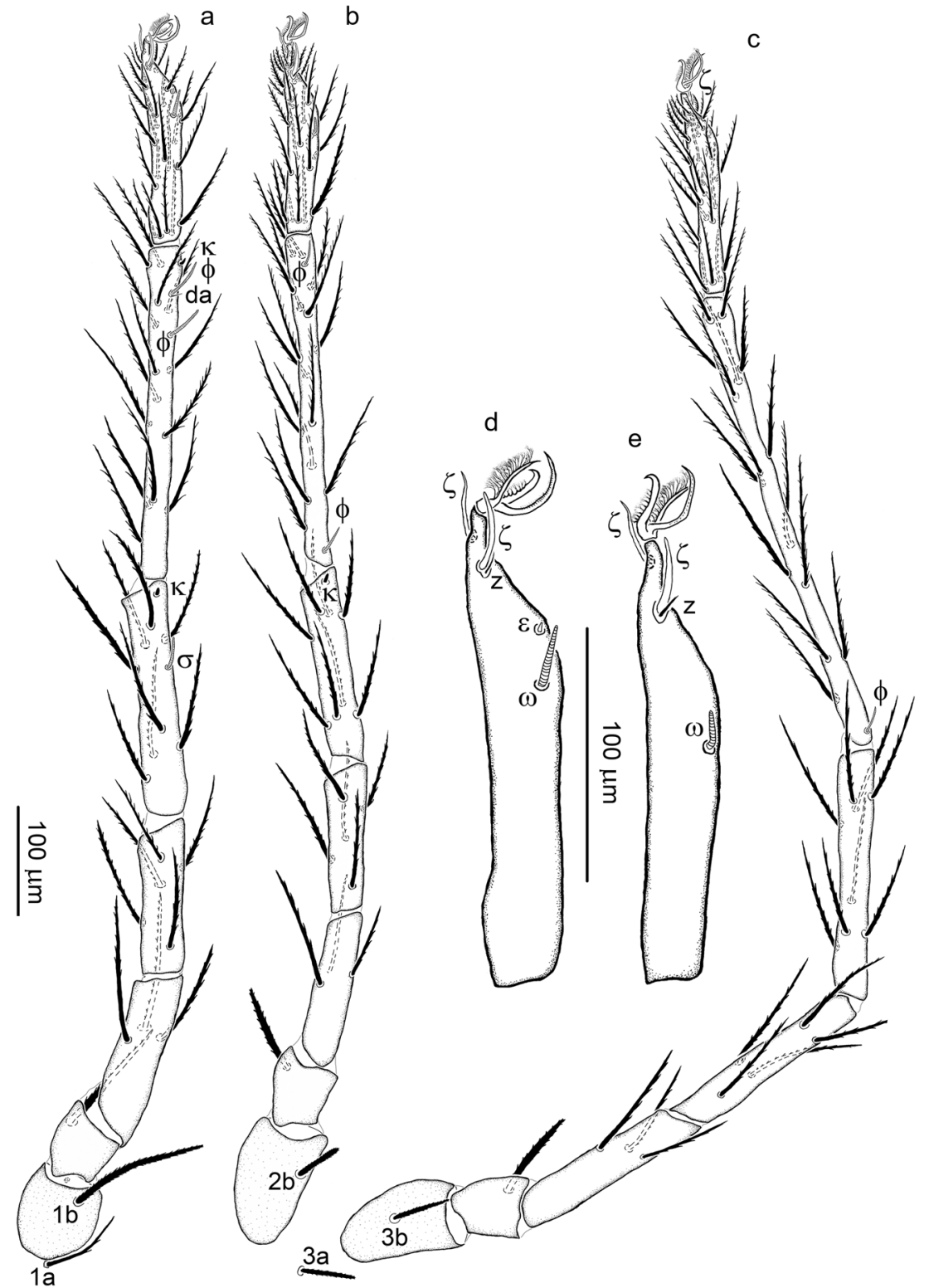

coasts over forested biotopes in lowlands to xeric meadows. In late May to July, deutonymphs and adults were observed to move quickly on the surface of litter layer and to feed on adult ants. Moreover, a single case of preying of adult $E$. phalangoides on a small beetle was observed. Larvae parasitized aphids in the field and in the laboratory.

During laboratory experiments, eggs underwent further development only after obligatory chilling, which provided a basis to consider the egg a diapausing and hibernating instar. In parasitism experiments, it was observed that unfed larvae attached to conspecifics which already had fed on a host. Such behavior was not observed when unfed larvae were kept together, without aphids. Spermatophore deposition was observed short time after collection in June. Spermatophores were deposited at subsaturated humidity conditions, only in the manner described by Witte (1991). Each spermatophore consisted of a whitish stalk (about $1200 \mu \mathrm{m}$ ) and a spherical sperm droplet (about $440 \mu \mathrm{m}$ ).

\section{E. cinereus (Dugès, 1834)}

Rhyncholophus cinereus Dugès, 1834

Erythraeus jowitae Haitlinger, 1987, syn. nov.

Erythraeus sp.: Wohltmann 1998

Erythraeus sp. A.: Wohltmann (2001)

Type material: Neotype (NHRS-ACAR 000000096), male (for the place of origin, see Table 1, locality 15, collection date: 28 July 1997), mounted on one slide, is deposited in the Swedish Museum of Natural History, Stockholm, Sweden

Diagnosis (data for neotype given in parentheses) 
Adult: Palp genu: 0-4 (2) semi-conalae; palp tibia: 4-6 conalae (5), 0-1 (0) semi-conalae; anterior sensillary area of crista metopica with anterior process and with 7-15 (11) non-sensillary setae; dorsal opisthosomal setae differentiated into two types, either straight or slightly bent, with husk-like setules; longer setae parallel sided or slightly narrowing apically, shorter-more distinctly narrowing towards termination; serratalae present on all legs, the most robust ones - on leg IV (see Fig. 8 for comparison)

Larva: AL not inflated basally, ASens long (60-90), $\mathrm{fD}=34-44, \mathrm{f}_{\mathrm{n}} \mathrm{bFe}=3-3-3$, Ti III 416-485

Description

Adult: Fig. 8; metric data: Table 3: meristic data: Table 5

Color in life reddish-brown, eyes bright red

Gnathosoma: Chelicerae typical for the genus; palps with relatively sparse setation; normal, setulated setae present on palp trochanter and palp femur; palp genu with strong, serrate setae dorsally, smooth and more slender setae laterally, zero to four semi-conalae (i.e. setae with rough, serrated surface, not more than twice as long as conalae, pointed); conalae absent from palp genu; palp tibia with normal, sparsely barbed setae and with four to six conalae and zero to one semi-conalae; odontus hook-like; palp tarsus hemispherical, with the apical part overreaching the termination of odontus, densely covered with eupathidia and solenidia

Idiosoma: Scutum roughly limited to crista metopica; anterior process of ASA distinct, posterior process of PSA absent; ASens and PSens covered with very tiny barbs; on ASA, $7-15$ setae AL; ocular plates $(70-80 \times 100-125)$, located laterally to crista, at about half of its length; dorsal setae (ca 40215) of two types (the most striking differences apply to the extreme forms); longer setae parallel sided or slightly narrowing apically, shorter-more distinctly narrowing towards termination, all covered with relatively stout setules;
Fig. 12 Erythraeus regalis, adult. a Palp, medial view. b Crista metopica and eyes. c Dorsal opisthosomal setae. d Serratala on genu I. e Serratala on genu IV. f Diversity of serratalae and setae of non-serratalae type on telofemora, genua, and tibiae of legs I-IV
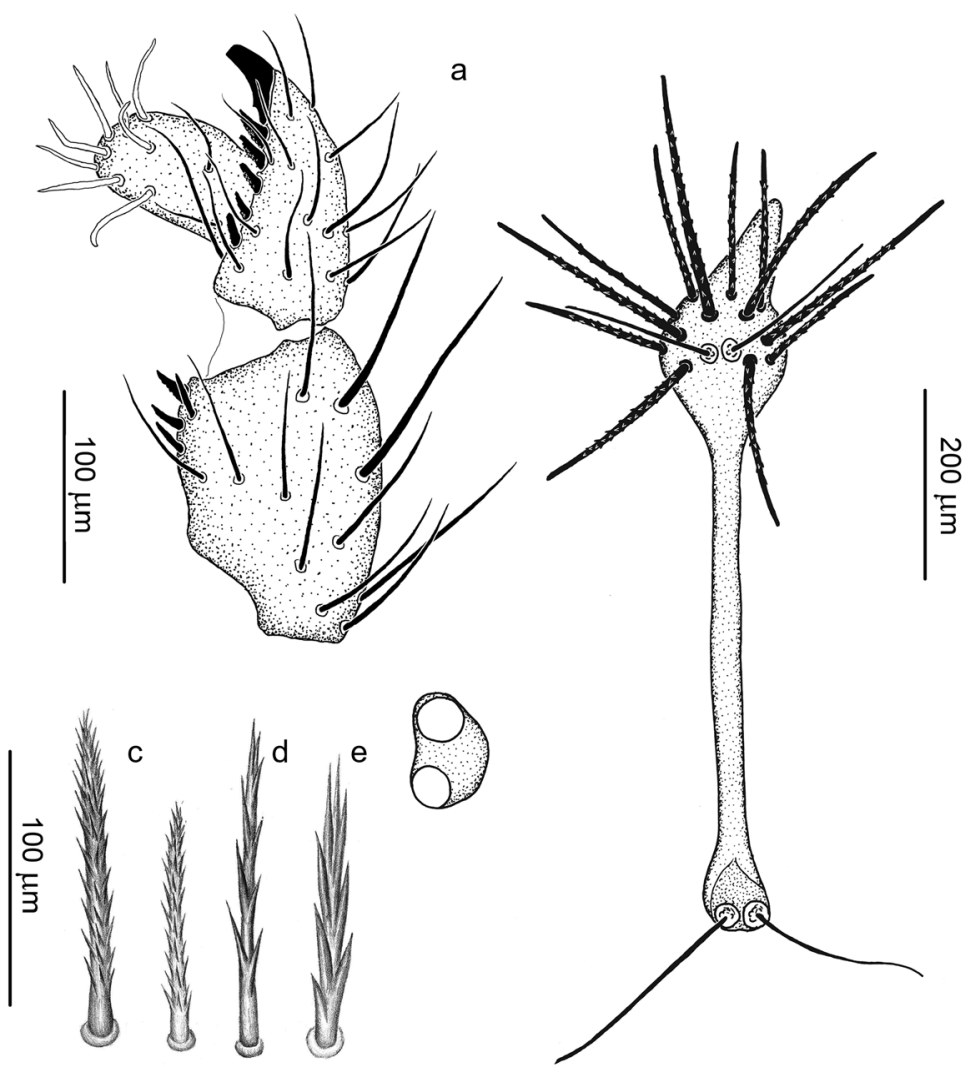

b 옹

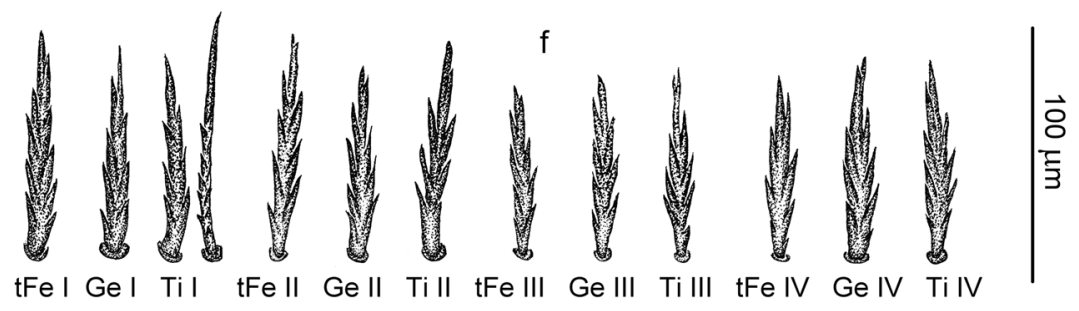


ventral setae much more slender than dorsal ones, covered with short setules. GOP surrounded by paired sclerites (genital plates: epivalves and centrovalves), located at the level of coxae III-IV; setae covering valves shorter than VS, slender, with delicate barbs; AOP surrounded by indistinct paired valves, and of those, the external valves are more sclerotized; setae covering valves similar to those covering genital plates but shorter

Legs: Serratalae present on basifemora, telofemora, genua, and tibiae of all legs; on legs I-II, more weakly developed than on legs III-IV; the most stout serratalae occur on tibia IV; of other setae - normal, setulated ones, present on all leg segments (on genua and tibiae - in minority); specialized setae distributed on bFe-Ta; Tarsi I-IV terminated in paired claws, each claw covered with fimbriae

Larva: Figures 9, 10, and 11; metric data: Table 4; meristic data (including leg chaetotaxy): Table 5

Color in life orange to reddish

Gnathosoma (Fig. 9): Cheliceral claw, with distinct subterminal hook on the blade; a pair of smooth, pointed adoral setae (cs) (31-48), located distally; paired, club-shaped, supracoxal setae (elcp, 4-6) placed dorsally, in antero-lateral position; on ventral side of gnathosoma - a pair of smooth, pointed subcapitular (hypostomal, tritorostral) setae (bs) (50-74) and, in more distal position, a pair of spine-like oral setae (as) (8-16); pedipalp formula: 0-B-B-BBB-BNNNNN $\omega \zeta z$; palp femur and genu, each with one setulated seta dorsally, palpal femoral seta (70-87) of similar length as palpal genual seta (70-95); setae on palp tibia covered with indistinct setules; odontus with dorsal, splinter-like branch, arising at half length of claw and not reaching claw termination; palp tarsus with one distinctly longer and five shorter, normal setae, one solenidion $(\omega)$ and one prominent distal eupathidium $(\zeta)$, the latter associated with tiny companion seta $(z)$

Idiosoma (Fig. 10): Scutum hexagonal in outline, widening postero-laterally; anterior border almost straight, lateral and posterior borders rounded; AL not widened at base, both AL and PL serrate; ASens slightly shorter than PSens; paired eyes located posterolaterally of scutum, anterior lens (22) slightly larger

Fig. 13 Erythraeus regalis, larva. a Gnathosoma, ventral view. b Palp tarsus

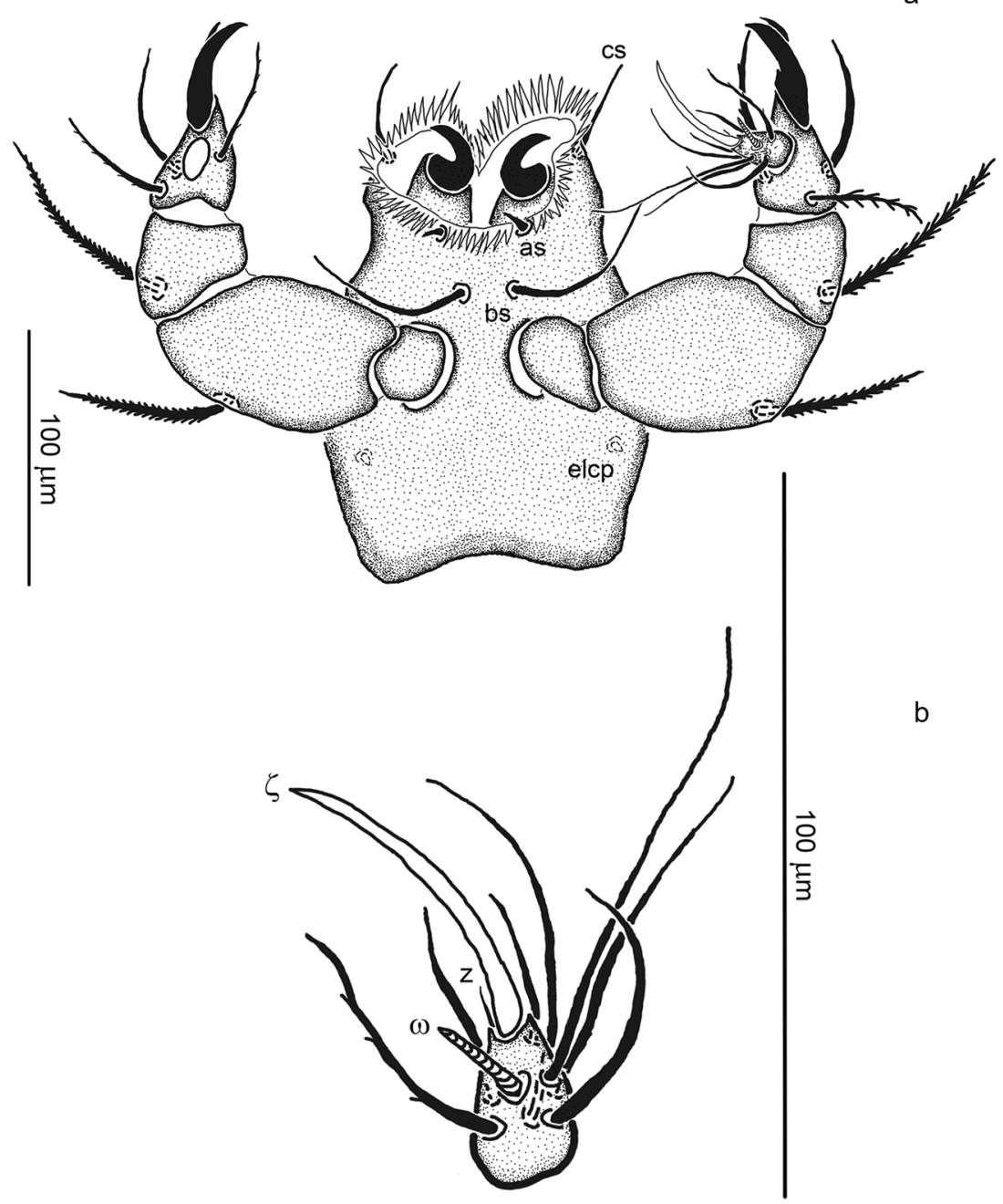


than the posterior lens (20); dorsal setae variable in length (59-143), serrate; NDV $=46-58$; coxa I with serrate seta $1 \mathrm{~b}(120-140)$, seta 1 a $(70-95)$ located outside coxal plate I; coxa II with serrate seta $2 \mathrm{~b}(40-60)$ (in one larva setae $2 b$ extraordinarily long, 100-105); coxa III with serrate seta $3 \mathrm{~b}$ (48-68); seta $3 \mathrm{a}(42-56)$ located outside coxa III; posterior to coxae III six pseudanal setae (55-60), distinctly thinner than dorsal idiosomal setae

Legs (Fig. 11): Segmentation formula: 7-7-7; solenidion on genu I (33-38) and solenidia on tibia I (30-40) of similar length; solenidion on genu $(\sigma)$ arising at ca half length of the segment; both solenidia on tibia $(\varphi)$ located in distal half of the segment, distal solenidion with companala $d a$; solenidion $(\omega)$ on tarsus I relatively short (25-32), famulus ( $)$ (4-5) small, inconspicuous; subterminal eupathidium on tarsus I also relatively short (30-40) and with accompanying seta $z$ (8-12), "pretarsal" eupathidium shorter (24-30), without $z$; all solenidia on leg II moderately short (20-30); solenidia on tibia II arise at proximal and distal margin of the segment, respectively; subterminal eupathidium on tarsus II (35-40) with companala $z$ (7-10), "pretarsal" eupathidium shorter (21-28), without $z$; solenidion on tibia III short (21-25), located proximally, "pretarsal" eupathidium (25-32), without $z$; median empodium of pretarsi I-III claw-like, with small lateral barbs; anterior claw with terminal hook, posterior claw without hook; both claws aliform

Distribution: Western Palaearctic

Remarks on taxonomy

Considering the set of morphological traits but also the ecological preferences and frequency of occurrence, larvae of E. cinereus match E. jowitae Haitlinger, 1987. The latter
Fig. 14 Erythraeus regalis, larva. a Gnathosoma and idiosoma, dorsal view. b Dorsal opisthosomal seta. c Gnathosoma and idiosoma, ventral view
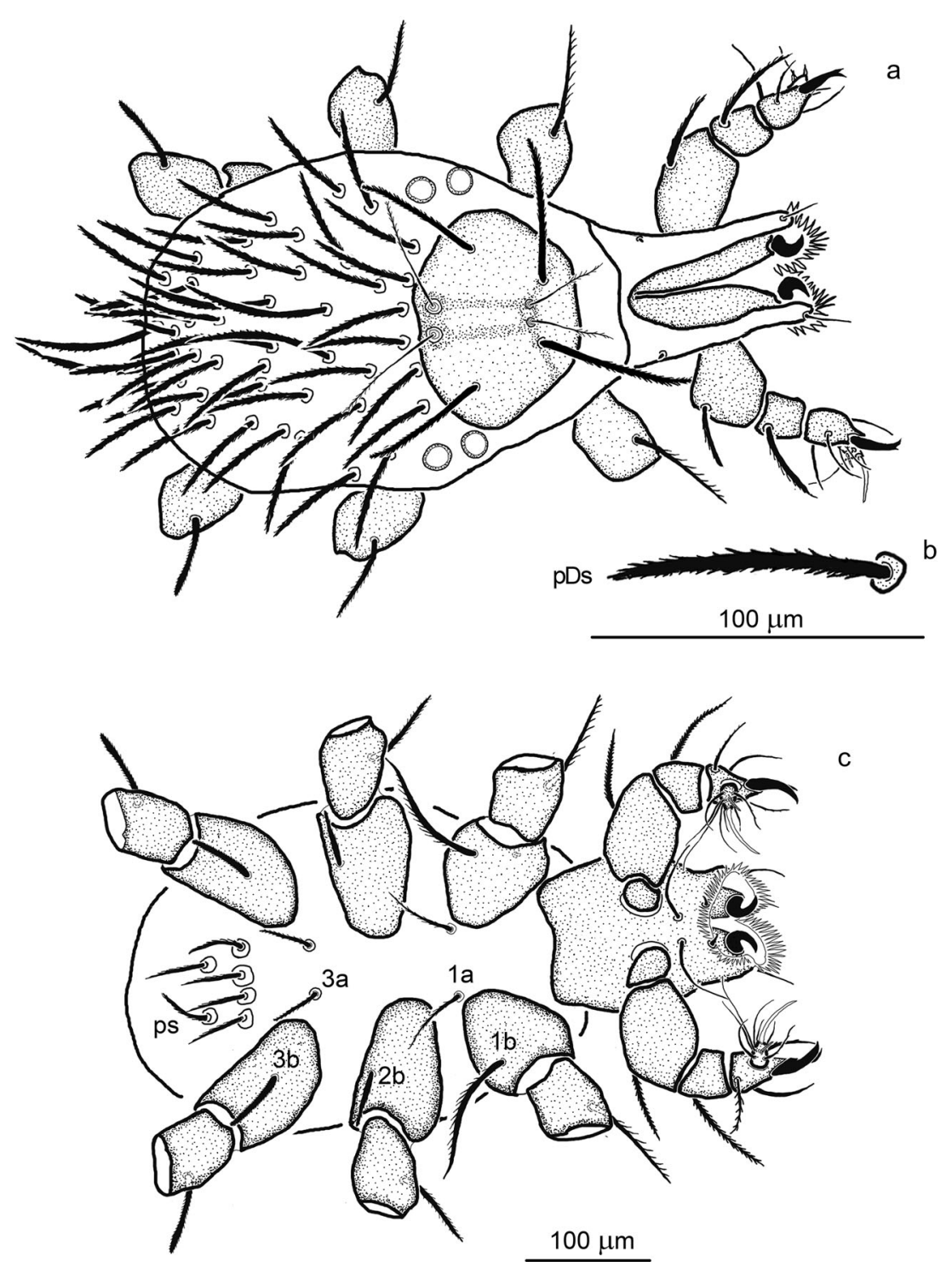
species was described based on two specimens and since then has been recorded from several European countries (see distribution). Here, it is considered as junior synonym of $E$. cinereus.

\section{Biology}

Field data and laboratory data are provided in Table 2. E. cinereus was collected at forests, forest margins, at flooded valleys and the reed belts on the ponds, at one locality part of the habitat was exposed to annual flooding by a nearby creek in winter and in spring. The maximum abundance of larvae was observed in July. Deutonymphs were found in litter layer. Adults were active at sunny days in August and September but remained motionless preferably at the underside of rotting leaves when temperatures were below $10^{\circ} \mathrm{C}$. In January and February, diapausing adults were sometimes found frozen but became active when exposed to $20{ }^{\circ} \mathrm{C}$ in the laboratory. In the field, adults became active again in spring, when they searched the surface of the litter layer for prey and mates.

In the laboratory, only adults collected in spring deposited eggs $(n=31)$, while females collected in autumn or winter never did so $(n=40)$. E. cinereus eggs remained viable at 76-100\% relative air humidity and survived even permanent submersion in tap water. Partially fed larvae became attractive as host to unfed conspecifics, which in turn started parasitism. These larvae could again become attractive to other unfed larvae, and in several cases, chains of up to four E. cinereus larvae parasitizing each other were found, which votes for the phenomenon of hyperparasitism existing in Erythraeus spp. In a few cases, both the larva parasitizing the aphid host as well as another larva parasitizing its conspecific reached the next life instar. However, in majority of cases, the uptake of nutrients from conspecifics was not sufficient and, after detachment, larvae continued to display host searching behavior, sometimes leaving larvae dead and sucked empty. Parasitism on unfed larvae of the same species was observed exceptionally $(n=3), 7$ days after hatching, and none of the parasitic larvae reached the subsequent life instar. Larvae of ants, nymphs, and adults of plant bugs were not accepted by $E$. cinereus larvae as potential hosts. Deutonymphs and adults fed on larvae and pupae of ants and brachyceran flies. Adults kept at constant $20^{\circ} \mathrm{C}$ moved around and fed on prey; however, neither spermatophores nor eggs were deposited. Exposure to $5{ }^{\circ} \mathrm{C}$ for 71 days again did not induce reproductive behavior after re-exposition to $20^{\circ} \mathrm{C}(n=15)$. However, when chilled for 105 days, males deposited spermatophores 5-7 days after re-exposition to $20^{\circ} \mathrm{C}(n=3)$, which points at adult as an hibernating instar.

\section{E. regalis (C.L. Koch, 1837)}

Rhyncholophus regalis C.L. Koch, 1837

Bochartia kuyperi Oudemans, 1910, syn. nov.

Erythraeus gertrudae Haitlinger, 1987, syn. nov.
Erythraeus sp. A.: Wendt (1996)

Erythraeus nivalis (sic!): Wohltmann (2001)

Type material: Neotype (NHRS-ACAR 000000097), female (for the place of origin, see Table 1, locality 23, collection date: 24 May 2015), mounted on one slide, is deposited in the Swedish Museum of Natural History, Stockholm, Sweden.

Diagnosis (data for neotype given in parentheses)

Adult: Palp genu: 0-3 (2) conalae, 0-2 (0) semiconalae; palp tibia: 2-5 (5) conalae, 0-2 (0) semiconalae; anterior sensillary area of crista metopica with anterior process and with 8-12 (12) non-sensillary setae; dorsal opisthosomal setae uniform in shape, straight or only slightly bent, narrowing apically, with slender, husk-like setules; serratalae on legs I-II slender, on legs III-IV moderately developed (see Fig. 12 for comparison)

Larva: AL not inflated basally, ASens relatively long (50 76), $\mathrm{fD}=30-42, \mathrm{f}_{\mathrm{n}} \mathrm{bFe}=3-3-3$, Ti III 310-385

Description

Adult: Fig. 12; metric data: Table 3; meristic data: Table 5

Color in life reddish-brown

Gnathosoma: Chelicerae typical for the genus; palps with relatively sparse setation; normal, setulated setae present on palp trochanter and palp femur; palp genu with almost smooth, slender setae (slightly thicker at dorsal side of the segment), zero to three conalae and zero to two semiconalae; palp tibia with normal, sparsely barbed setae and with two to five conalae and zero to two semi-conalae; odontus hook-like; palp tarsus rounded at termination, with the apical part overreaching the termination of odontus, densely covered with eupathidia and solenidia

Idiosoma: Scutum indistinct, not extended beyond crista metopica; anterior process of ASA relatively narrow, posterior process of PSA absent; ASens and PSens covered with very tiny barbs; on ASA $-8-12$ setae AL; ocular plates $(73-88 \times 108-127)$, located laterally to crista, behind the half of its length; dorsal setae (50-175) uniform in shape, only slightly narrowing apically, densely covered with husk-like setules (more delicate than in E. cinereus); setules adnate in proximal part of the stem, become more outstanding towards stem termination; ventral setae much more slender than dorsal ones, needle-like, covered with short bristles; GOP surrounded by paired sclerites (genital plates: epivalves and centrovalves), located at the level of coxae III-IV; setae covering valves similar to VS, slender, with delicate barbs; AOP surrounded by indistinct paired valves, and of those, the external valves were more sclerotized; setae covering valves similar to those covering genital plates but shorter

Legs: Serratalae present on basifemora, telofemora, genua, and tibiae of all legs; on legs I-II serratalae slender than on 
legs III-IV; the most stout serratalae occur on tibia IV; of other setae - normal, setulated ones, present on all leg segments (on genua and tibiae - in minority); specialized setae distributed on bFe-Ta; tarsi I-IV terminated in paired claws, each claw covered with fimbriae

Larva: Figs. 13, 14, 15, and 16; metric data: Table 4; meristic data (including leg chaetotaxy): Table 5

Color in life bright red

Gnathosoma (Fig. 13): Cheliceral claw, with distinct subterminal hook on the blade; a pair of smooth, pointed adoral setae (cs) (33-46), located distally; paired, club-shaped, supracoxal setae (elcp, 5-7) placed dorsal$1 y$, in antero-lateral position; on ventral side of gnathosoma, a pair of smooth, pointed subcapitular (hypostomal, tritorostral) setae $(b s)(56-69)$ and, in more distal position, a pair of spine-like oral setae (as) (6-15); pedipalp formula: 0-B-B-BBB-BNNNNN $\omega \zeta z$; palp femur and genu, each with one setulated seta dorsally, palpal femoral seta (60-71), slightly shorter than palpal genual seta (79-91); the most proximal seta on palp tibia with short setules, the most distally placed seta (in ventral position) almost smooth; odontus with dorsal, splinter-like branch, arising at half length of claw and not reaching claw termination; palp tarsus with one elongated, barbed seta, and five to six shorter, normal setae (two-with minute setules), one solenidion $(\omega)$ and one prominent distal eupathidium $(\zeta)$, the latter associated with tiny companion seta $(z)$

Idiosoma (Figs. 14 and 15): Scutum oval to trapezoidal in shape; AL not widened at base, both AL and PL serrate;

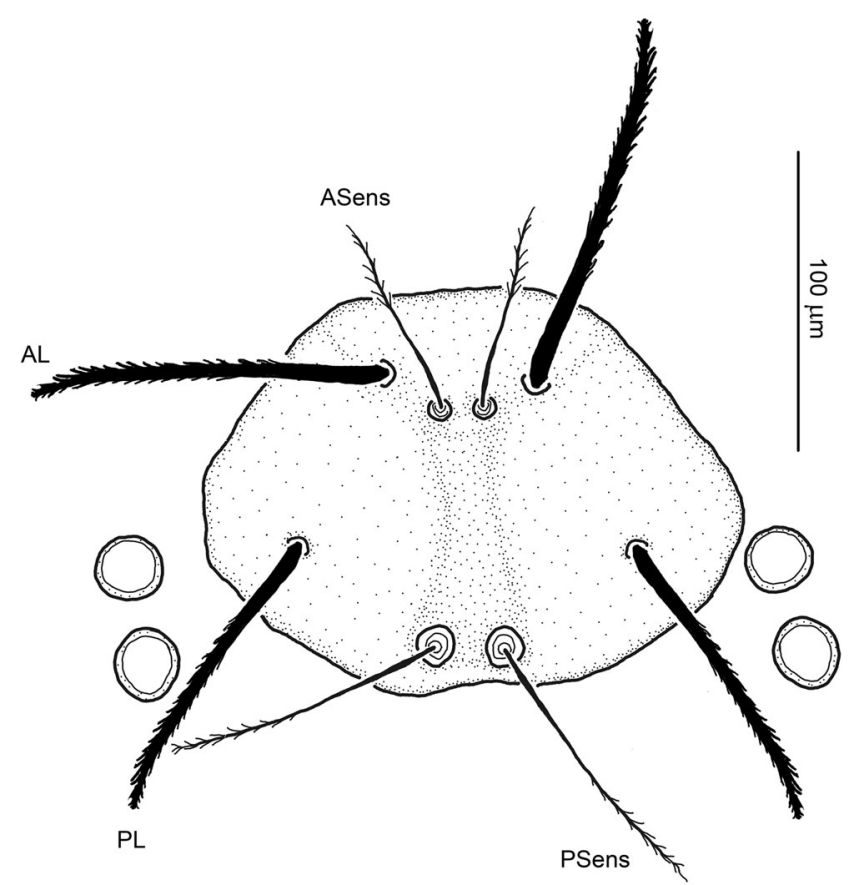

Fig. 15 Erythraeus regalis, larva. Scutum
ASens shorter than PSens; paired eyes located posterolaterally of scutum, at the level of posterior margin of the sclerite (in unengorged specimens); anterior lens (18-19) and posterior lens (17-19) comparable in size; dorsal setae variable in length $(58-127)$, serrate; $\mathrm{NDV}=42-52$; seta $1 \mathrm{a}$ (60-70) located outside coxal plate I; coxa I with serrate seta 1b (106-120), coxa II with serrate seta 2 b (43-44), coxa III with serrate seta $3 \mathrm{~b}(49-53)$; seta $3 \mathrm{a}$ (38-43) located outside coxa III; posterior to coxae III six pseudanal setae $(50-58)$, distinctly thinner than dorsal idiosomal setae

Legs (Fig. 16): Segmentation formula: 7-7-7; solenidion on genu I (25-27) located at ca half length of the segment; proximal solenidion on tibia I (28-30) slightly shorter than the distal solenidion (32-36); both solenidia on tibia located in distal half of the segment, distal solenidion with companala $d a$; solenidion $(\omega)$ on tarsus I relatively short (24-28), famulus ( $\varepsilon$ ) (3) small, inconspicuous; subterminal eupathidium on tarsus I also relatively short (32-35) and with accompanying seta $z$ (9), "pretarsal" eupathidium markedly shorter (17-20), without $z$; solenidia on tibia II arise at proximal and distal margin of the segment, respectively; proximal solenidion (21-24) longer than the distal one (15); subterminal eupathidium on tarsus II (34-38) with companala $z$ (9), "pretarsal" eupathidium shorter (23-25), without $z$; solenidion on tibia III short (22-25), located proximally, "pretarsal" eupathidium (19-27), without $z$; median empodium of pretarsi I-III claw-like, with small lateral barbs; anterior claw with terminal hook, posterior claw without terminal hook; both claws aliform

Distribution: Western Palaearctic

Remarks on taxonomy

E. kuyperi and E. gertrudae fall within the range of morphometric characters as measured for larvae of E. regalis. Haitlinger (2003), in the key to larvae of Erythraeus spp., pointed to differences between E. kuyperi and E. gertrudae expressed in the shape of scutum (oval in E. kuyperi, trapezoidal in E. gertrudae). Examination of larvae obtained by experimental rearing allowed to attribute the differences to intraspecific variation, thus constitutes the background for species synonymization.

Biology

Field data and laboratory data are provided in Table 2. E. regalis was collected close to water reservoirs, both in meadows and in forested areas, however not at inundated places. A single protonymph was collected in the litter layer in August. Deutonymphs were active at sunny days in August-September and again in March moved around on the litter layer. Outside the time of increased activity, they hid in crevices of the bark of Betula 1-3 m above ground level. In May 16, tritonymphs were found in crevices, most in the bark of birch trees and only few in the litter layer. Adults were active in May-June. 
Fig. 16 Erythraeus regalis, larva. a Leg I. b Leg II. c Leg III. d Genu-tarsus I. e Genu-tarsus II. Tibia-tarsus III (d-f, only specialized setae shown)
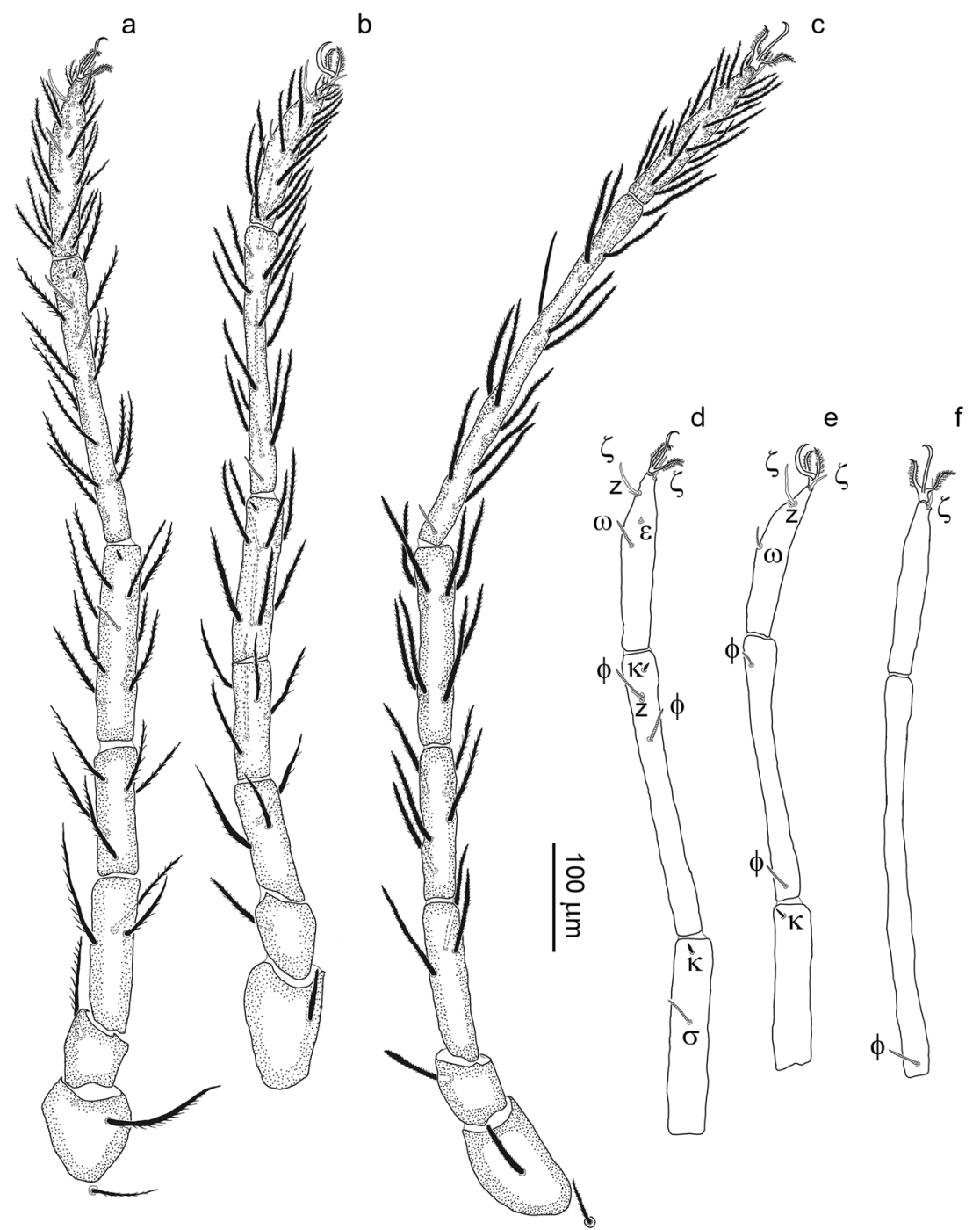

In the laboratory, eggs were deposited by females collected in early summer. Larvae hatched a month later and survived for up to 13 days without hosts $\left(n=60,20^{\circ} \mathrm{C}\right)$. When exposed to Aphis sp., larvae attached to the host at first contact. Further development stopped when reaching the deutonymph instar. Although deutonymphs moved and fed on larvae and pupae of ants and brachyceran flies, none entered the tritonymph when kept at constant $20^{\circ} \mathrm{C}$. However, of ten deutonymphs captured in September and chilled at $5{ }^{\circ} \mathrm{C}$ and darkness for 102 days, one entered the tritonymph when subsequently exposed to $20^{\circ} \mathrm{C}$ and $16 / 8$ light/darkness. The latter constitutes an evidence for deutonymph being a diapausing and hibernating instar.

\section{Concluding remarks}

For E. regalis and E. cinereus, the results of the molecular analysis were confirmed by laboratory rearing. In case of E. phalangoides, matching of larvae and active postlarval forms was based on the results of experimental rearing, whereas the distinct ID of the species was confirmed by molecular data. Both molecular analyses and experimental rearing allowed for unambiguous correlation of heteromorphic instars and, in consequence, subsequent morphological investigations of specimens collected at different geographical areas.

The correlation of heteromorphic, metamorphosed instars through DNA analysis and laboratory rearing has been infrequently applied up to date in relation to various non-parasitengone arthropods (Grutter et al. 2000; Barros-Battesti et al. 2007; Kumar et al. 2007; González et al. 2015). As application of both methods led to the same results, we are convinced that DNA barcoding is a highly cost-effective alternative or complement to experimental rearing practice, especially when it comes to problematic species (Hebert et al. 2003; Kress et al. 2015). The plethora of studies now using solely DNA- 
based species identification to link life history stages and to study trophic interactions is a convincing testimony (see references in "Introduction"). In both cases, the sampling effort is comparable, however, with slightly different approach. While the collecting of active postlarval forms for the purpose of molecular delimitation does not need to focus on ovigerous females, the arthropod-parasitizing larvae require complementary collecting methods.

Although rearing gives a vital insight in the species biology, the disadvantage is the time. The faster genetic matching has its flaws in laboratory costs and requires access to molecular facilities. On the other hand, the per base pair sequencing cost has plummeted in the last 10 years, thanks to highthroughput Sanger sequencing workflows as well as nextgeneration sequencing techniques. DNA-based species identification also has a number of challenges in the need of a representative reference library and can be misled by hybridization, introgression, incomplete lineage sorting, or young species radiation (see "Introduction"). Species delimitation using the GMYC model can be sensitive to low sampling, both at population level and at taxonomic scale (Lohse 2009). In our case, the inclusion of additional species of the same genus resulted in increased support in the gene tree and gave better performance in the species delimitation (narrowing the confidence interval). Also the possibility of contamination (gut content from host/prey) is harder to detect with fewer samples. As we observed, conspecific parasitism under laboratory conditions, it is not impossible that parasitism can occur in the wild between closely related species. DNA contamination from gut contents in such case could be very difficult to detect. Of several molecular species delimitation models, the GMYC model has the advantage of not requiring any predefined units. It is a so-called discovery method of species delimitation in contrast to validation methods that require a predefined hypothesis of species limits (Ence and Carstens 2011; Carstens et al. 2013). In this study, the combination of experimental rearing and molecular matching contributed to the knowledge of intraspecific variation of metric data and strengthened the conclusions resulting in formal synonymization of several nominal species names. This is a first step on the way towards resolving the double classification in Erythraeus and other parasitengone mites. As stated by de Queiroz (2007), assembling morphological, biological, and molecular data, gives multiple lines of evidence to species hypotheses in a unified species concept framework.

Acknowledgments We are grateful to all collectors who helped to obtain the specimens for studies. The staff at the Molecular Systematics Laboratory (MSL, NRM) is acknowledged for their valuable advice on sequencing. Our thanks go to D. Łupicki for his assistance in processing the original drawings of setae in postlarval forms of Erythraeus spp. JS and JB were supported (grant dha 154/09 1.4) by the Swedish Taxonomy Initiative.
Open Access This article is distributed under the terms of the Creative Commons Attribution 4.0 International License (http:// creativecommons.org/licenses/by/4.0/), which permits unrestricted use, distribution, and reproduction in any medium, provided you give appropriate credit to the original author(s) and the source, provide a link to the Creative Commons license, and indicate if changes were made.

\section{References}

Ahrens, D., Monaghan, M. T., \& Vogler, A. P. (2007). DNA-based taxonomy for associating adults and larvae in multi-species assemblages of chafers (Coleoptera: Scarabaeidae). Molecular Phylogenetics and Evolution, 44, 436-449.

Alcántar-Escalera, F. J., García-Varela, M., Vázquez-Domínguez, E., \& Pérez-Ponce de León, G. (2013). Using DNA barcoding to link cystacanths and adults of the acanthocephalan Polymorphus brevis in central Mexico. Molecular Ecology Resources, 13, 1116-1124.

Avelino-Capistrano, F., Nessimian, J. L., Santos-Mallet, J. R., \& Takiya, D. M. (2014). DNA-based identification and descriptions of immatures of Kempnyia Klapálek (Insecta: Plecoptera) from Macaé River Basin, Rio de Janeiro State, Brazil. Freshwater Science, 33, 325 337.

Baldwin, C. C., \& Johnson, G. D. (2014). Connectivity across the Caribbean Sea: DNA barcoding and morphology unite an enigmatic fish larva from the Florida Straits with a new species of sea bass from deep reefs off Curaçao. PLoS ONE, 9(5), e97661. doi:10.1371/ journal.pone.0097661.

Barros-Battesti, D. M., Onofrio, V. C., Faccini, J. L., Labruna, M. B., Arruda-Santos, A. D., \& Giacomin, F. G. (2007). Description of the immature stages and redescription of the female of Ixodes schulzei Aragão \& Fonseca, 1951 (Acari: Ixodidae), an endemic tick species of Brazil. Systematic Parasitology, 68, 157-166.

Basset, Y., Cizek, L., Cuénoud, P., Didham, R. K., Guilhaumon, F., Missa, O., Novotny, V., Ødegaard, F., Roslin, T., Schmidl, J., Tishechkin, A. K., Winchester, N. N., Roubik, D. W., Aberlenc, H.-P., Bail, J., Barrios, H., Bridle, J. R., Castaño-Meneses, G., Corbara, B., Curletti, G., da Rocha, W. D., Bakker, D. D., Delabie, J. H. C., Dejean, A., Fagan, L. L., Floren, A., Kitching, R., Medianero, E., Miller, S. E., de Oliveira, E. G., Orivel, J., Pollet, M., Rapp, M., Ribeiro, S. P., Roisin, Y., Schmidt, J. B., Sørensen, L., \& Leponce, M. (2012). Arthropod diversity in a tropical forest. Science, 33(6113), 1481-1484.

Bergsten, J., Bilton, D. T., Fujisawa, T., Elliott, M., Monaghan, M. T., Balke, M., Hendrich, L., Geijer, J., Herrmann, J., Foster, G. N., Ribera, I., Nilsson, A. N., Barraclough, T. G., \& Vogler, A. P. (2012). The effect of geographical scale of sampling on DNA barcoding. Systematic Biology, 61, 851-869.

Beron, P. (1982). Deuxième contribution à l'étude des Erythraeidae (Acariformes) larvaires de Bulgarie. Acta Zoologica Bulgarica, 19, $46-56$.

Beron, P. (2008). Acarorum Catalogus I. Acariformes: Calyptostomatoidea (Calyptostomatidae), Erythraeoidea (Smarididae, Erythraeidae). Pensoft Publishers and the National Museum of Natural History, Sofia; Bulgarian Academy of Sciences, Sofia-Moscow.

Billberg, G. (1820). Enumeratio insectorum in Museo Gust. Joh. Billberg. Stockholm: Typis Gadelianis.

Bouckaert, R., Heled, J., Kühnert, D., Vaughan, T. G., Wu, C.-H., Xie, D., Suchard, M. A., Rambaut, A., \& Drummond, A. J. (2014). BEAST2: a software platform for Bayesian evolutionary analysis. PLoS Computational Biology, 10(4), e1003537.

Brown, J. M., Hedtke, S. M., Lemmon, A. R., \& Lemmon, E. M. (2010). When trees grow too long: investigating the causes of highly 
inaccurate Bayesian branch-length estimates. Systematic Biology, $59,145-161$.

Campbell, B. C., Steffen-Campbell, J. D., \& Werren, J. H. (1993). Phylogeny of the Nasonia species complex (Hymenoptera: Pteromalidae) inferred from an internal transcribed spacer (ITS2) and 28S rDNA sequences. Insect Molecular Biology, 2, 225-237.

Carstens, B. C., Pelletier, T. A., Reid, N. M., \& Satler, J. D. (2013). How to fail at species delimitation. Molecular Ecology, 22, 4369-4383.

Caterino, M. S., \& Tishechkin, A. (2006). DNA identification and morphological description of the first confirmed larvae of Hetaeriinae (Coleoptera, Histeridae). Systematic Entomology, 31, 405-418.

Cruickshank, R. H. (2002). Molecular markers for the phylogenetics of mites and ticks. Systematic and Applied Acarology, 7, 3-14.

Dabert, J., Ehrnsberger, R., \& Dabert, M. (2008). Glaucalges tytonis sp. n. (Analgoidea, Xolalgidae) from the barn owl Tyto alba (Strigiformes, Tytonidae): compiling morphology with DNA barcode data for taxon descriptions in mites (Acari). Zootaxa, $1719,41-52$.

De Geer, C. (1778). Mémoires pour servir à l'histoire des Insectes (Vol. 7, pp. 134-136). Stockholm: Imprimerie Pierre Hesselberg.

de Queiroz, K. (2007). Species concepts and species delimitation. Systematic Biology, 56, 879-886.

Dugès, A. L. (1834). Recherches sur l'ordre des acariens en général et la famille des trombides en particulier. Annales des Sciences Naturelles, Zoologie, 2, 5-46.

Ence, D. D., \& Carstens, B. C. (2011). SpedeSTEM: a rapid and accurate method for species delimitation. Molecular Ecology Resources, 11, 473-480.

Erwin, T. L. (1982). Tropical forests: their richness in Coleoptera and other arthropod species. Coleopterists Bulletin, 36, 74-75.

Ezard, T., Fujisawa, T., \& Barraclough, T. G. (2014). SPLITS: species' limits by threshold statistics. (Available from: https://r-forge.rproject.org/projects/splits/).

Feller, K. D., Cronin, T. W., Ahyong, S. T., \& Porter, M. L. (2013). Morphological and molecular description of the late-stage larvae of Alima Leach, 1817 (Crustacea: Stomatopoda) from Lizard Island, Australia. Zootaxa, 3722, 22-32.

Fujisawa, T., \& Barraclough, T. G. (2013). Delimiting species using single-locus data and the generalized mixed Yule coalescent (GMYC) approach: a revised method and evaluation on simulated datasets. Systematic Biology, 62, 707-724.

Gattolliat, J. L., \& Monaghan, M. T. (2010). DNA-based association of adults and larvae in Baetidae (Ephemeroptera) with the description of a new genus Adnoptilum in Madagascar. Journal of the North American Benthological Society, 29, 1042-1057.

González, C. R., Reyes, C., \& Rada, V. (2015). Redescription of the adults and new descriptions of the previously unknown immature stages of Culex (Culex) articularis Philippi, 1865 (Diptera: Culicidae) from central Chile. Zootaxa, 3955, 444-450.

Goolsby, J. A., DeBarro, P. J., Makinson, J. R., Pemberton, R. W., Hartley, D. M., \& Frohlich, D. R. (2006). Matching the origin of an invasive weed for selection of a herbivore haplotype for a biological control programme. Molecular Ecology, 15, 287-297.

Grandjean, F. (1947). Étude sur les Smarisidae et quelques autres Erythroides (Acariens). Archives Zoologie Experimentale et Generale, 85, 1-126.

Grutter, A. S., Morgan, J. A. T., \& Adlard, R. D. (2000). Characterising parasitie gnathiid isopod species and matching life stages with ribosomal DNA ITS2 sequences. Marine Biology, 136, 201-205.

Haarløv, N. (1957). Microarthropods from Danish soils. Spolia Zoologica Musei Hauniensis, 17, 1-60.

Haitlinger, R. (1987). The genus Erythraeus Latreille, 1806 (Acari, Prostigmata, Erythraeidae) in Poland (larvae). Bulletin Entomologique de Pologne, 57, 725-734.

Haitlinger, R. (2003). Four new larval Erythraeidae (Acari, Prostigmata) from Rhodos, Greece. Biologia, Bratislava, 58, 133-146.
Haitlinger, R., \& Šundić, M. (2015). Erythraeus (Zaracarus) tuzicus n. sp. from Montenegro and redescription of Erythraeus (Zaracarus) eleonorae Haitlinger, 1987 (Acari: Prostigmata, Erythraeidae). Acarologia, 55, 189-200. doi:10.1051/acarologia/20152160.

Haldeman, S. (1842). On some American species of Hydrachnidae. An account of some hitherto unnoticed species of the genus Hydrachna, Müller. Zoological Contributions, Philadelphia, 1, 1-6.

Hebert, P. D. N., \& Gregory, R. T. (2005). The promise of DNA barcoding for taxonomy. Systematic Biology, 54, 852-859.

Hebert, P. D. N., Cywinska, A., Ball, S. L., \& de Waard, J. R. (2003). Biological identifications through DNA barcodes. Proceedings of the Royal Society of London, Series B-Biological Sciences, 270, 313-321.

Hickerson, M. J., Meyer, C. P., \& Moritz, C. (2006). DNA barcoding will often fail to discover new animal species over broad parameter space. Systematic Biology, 55, 729-739.

Hubert, N., Delrieu-Trottin, E., Irisson, J. O., Meyer, C., \& Planes, S. (2010). Identifying coral reef fish larvae through DNA barcoding: a test case with the families Acanthuridae and Holocentridae. Molecular Phylogenetics and Evolution, 55, 1195-1203.

Johanson, K. A. (2007). Association and description of males, females and larvae of two New Caledonian Xanthochorema species (Trichoptera: Hydrobiosidae) based on mitochondrial 16S and COI sequences. Entomological Science, 10, 179-199.

Jousson, O., Bartoli, P., \& Pawlowski, J. (1999). Molecular identification of developmental stages in Opecoelidae (Digenea). International Journal for Parasitology, 29, 1853-1858.

Kamran, M., \& Alatawi, F. J. (2014). Erythraeid mites (Prostigmata, Erythraeidae) from Saudi Arabia, description of three new species and a new record. ZooKeys, 445, 77-95. doi:10.3897/zookeys.445. 7861.

Kamran, M., Afzal, M., Raza, A. M., Bashir, M. H., \& Ahmad, S. (2011). Discovery of subgenus Erythraeus (Acari: Erythraeidae: Erythraeus) from Punjab, Pakistan. Pakistan Journal of Zoology, 43, 1055-1059.

Kamran, M., Afzal, M., \& Bashir, M. H. (2013). A new species of genus Erythraeus (Acari: Erythraeidae) from Punjab, Pakistan. Pakistan Journal of Zoology, 45, 35-39.

Katoh, K., \& Standley, D. M. (2013). MAFFT multiple sequence alignment software version 7: improvements in performance and usability. Molecular Biology and Evolution, 30, 772-780. doi:10.1093/ molbev/mst010.

Kawashima, K. (1961). On the occurrence of the genus Erythraeus Latreille in Japan, with key to known genera and species of larval Erythraeidae (Acarina). Kyushu Journal of Medical Science, 12, 233-239.

Kimura, M. (1980). A simple method for estimating evolutionary rate of base substitution through comparative studies of nucleotides sequences. Journal of Molecular Evolution, 16, 111-120.

Koch, C. L. (1837). Deutschlands Crustaceen, Myriapoden und Arachniden: ein Beitrag zur deutschen Fauna. Regensburg: F. Pustet.

Koch, C. L. (1842). Übersicht des Arachnidensystems. Heft 3, C.H. Zeh, Nürnberg.

Kress, W. J., García-Robledo, C., Uriarte, M., \& Erickson, D. L. (2015). DNA barcodes for ecology, evolution, and conservation. Trends in Ecology \& Evolution, 30, 25-35.

Kumar, N. P., Rajavel, A. R., Natarajan, R., \& Jambulingam, P. (2007). DNA barcodes can distinguish species of Indian mosquitoes (Diptera: Culicidae). Journal of Medical Entomology, 44, 1-7.

Latreille, P. A. (1806). Genera crustaceorum et insectorum secudnum ordinem naturalem in familias disposita, iconibus exemplisque plurimis explicata. Ed. Argentorati-A. Koenig, I, 146.

Łaydanowicz, J., \& Mąkol, J. (2010). Correlation of heteromorphic life instars in terrestrial Parasitengona mites and its impact on taxonomy — the case of Leptus molochinus (C. L. Koch, 1837) and Leptus 
ignotus (Oudemans, 1903) (Acari: Trombidiformes: Prostigmata: Erythraeidae). Journal of Natural History, 44, 669-697.

Lefort, M. C., Boyer, S., Worner, S. P., \& Armstrong, K. (2012). Noninvasive molecular methods to identify live scarab larvae: an example of sympatric pest and nonpest species in New Zealand. Molecular Ecology Resources, 12, 389-395.

Levkanicova, Z., \& Bocak, L. (2009). Identification of net-winged beetle larvae (Coleoptera: Lycidae) using three mtDNA fragments: a comparison of their utility. Systematic Entomology, 34, 210-221.

Locke, S. A., McLaughlin, J. D., Lapierre, A. R., Johnson, P. T., \& Marcogliese, D. J. (2011). Linking larvae and adults of Apharyngostrigea cornu, Hysteromorpha triloba, and Alaria mustelae (Diplostomoidea: Digenea) using molecular data. Journal of Parasitology, 97, 846-851.

Lohse, K. (2009). Can mtDNA barcodes be used to delimit species? A response to Pons et al. (2006). Systematic Biology, 8, 439-442.

Mahmoudi, F., Saboori, A., Sari, A., \& Hakimitabar, M. (2014). A new species of larval Erythraeus (Zaracarus) (Acari: Trombidiformes: Erythraeidae) from Iran, with a key to the world species of the subgenus. Systematic and Applied Acarology, 19, 79-86.

Mąkol, J. (2010). A redescription of Balaustium murorum (Hermann, 1804) (Acari: Prostigmata: Erythraeidae) with notes on related taxa. Annales Zoologici, 60, 439-454.

Mąkol, J., \& Wohltmann, A. (2012). An annotated checklist of terrestrial Parasitengona (Actinotrichida: Prostigmata) of the world, excluding Trombiculidae and Walchiidae. Annales Zoologici, 62, 359-562.

Mąkol, J., \& Wohltmann, A. (2013). Corrections and additions to the checklist of terrestrial Parasitengona (Actinotrichida: Prostigmata) of the world, excluding Trombiculidae and Walchiidae. Annales Zoologici, 63, 15-27.

Martin, P., Dabert, M., \& Dabert, J. (2010). Molecular evidence for species separation in the water mite Hygrobates nigromaculatus Lebert, 1879 (Acari, Hydrachnidia): evolutionary consequences of the loss of larval parasitism. Aquatic Sciences, 72, 347-360.

Miller, K. B., Alarie, Y., Wolfe, G. W., \& Whiting, M. F. (2005). Association of insect life stages using DNA sequences: the larvae of Philodytes umbrinus (Motschulsky) (Coleoptera: Dytiscidae). Systematic Entomology, 30, 499-509.

Mynott, J. H., Webb, J. M., \& Suter, P. J. (2011). Adult and larval associations of the alpine stonefly genus Riekoperla McLellan (Plecoptera: Gripopterygidae) using mitochondrial DNA. Invertebrate Systematics, 25, 11-21.

Nylander, J. A. A. (2004). MrModeltest v2. Program distributed by the author. Evolutionary Biology Centre, Uppsala University.

Okassa, M., Kreiter, S., \& Tixier, M. S. (2012). Obtaining molecular data for all life stages of Typhlodromus (Typhlodromus) exhilaratus (Mesostigmata: Phytoseiidae): consequences for species identification. Experimental and Applied Acarology, 57, 105-116.

Oudemans, A. C. (1910). Acarologische aanteekeningen. XXX. Entomologische Berichten, 51, 29-34.

Oudemans, A. C. (1929). Kritisch historisch Overzicht der Acarologie II, E. J. Brill, pp. 587-592.

Pfenninger, M., Nowak, C., Kley, C., Steinke, D., \& Streit, B. (2007). Utility of DNA taxonomy and barcoding for the inference of larval community structure in morphologically cryptic Chironomus (Diptera) species. Molecular Ecology, 16, 1957-1968.

Pons, J., Barraclough, T. G., Gomez-Zurita, J., Cardoso, A., Duran, D. P., Hazell, S., Kamoun, S., Sumlin, W. D., \& Vogler, A. P. (2006). Sequence-based species delimitation for the DNA taxonomy of undescribed insects. Systematic Biology, 55, 595-609.

Prado, B. R., Pozo, C., Valdez-Moreno, M., \& Hebert, P. D. (2011). Beyond the colours: discovering hidden diversity in the Nymphalidae of the Yucatan Peninsula in Mexico through DNA barcoding. PLoS ONE, 6(11), e27776. doi:10.1371/journal.pone. 00277766 .
R Core Team. (2015). R: a language and environment for statistical computing. R Foundation for Statistical Computing, Vienna, Austria, URL. Available from http://www.Rproject. org/.

Robineau-Desvoidy, J. B. (1828). Recherches sur l'organisation vertébrale des Crustacés, des Arachnides et des Insectes. Paris: Compère Jeune Libraire-Éditeur.

Ronquist, F., Teslenko, M., van der Mark, P., Ayres, D. L., Darling, A., Höhna, S., Larget, B., Liu, L., Suchard, M. A., \& Huelsenbeck, J. P. (2012). MrBayes 3.2: efficient Bayesian phylogenetic inference and model choice across a large model space. Systematic Biology, 61, $539-542$.

Sequencher®. (2008). Sequence analysis software version 4.10.1. Gene Codes Corporation, Ann Arbor, MI USA, http://www.genecodes. com.

Skoracka, A., \& Dabert, M. (2010). The cereal rust mite Abacarus hystrix (Acari: Eriophyoidea) is a complex of species: evidence from mitochondrial and nuclear DNA sequences. Bulletin of Entomological Research, 100, 263-272.

Skoracka, A., Kuczyński, L., Szydło, W., \& Rector, B. (2013). The wheat curl mite Aceria tosichella (Acari: Eriophyoidea) is a complex of cryptic lineages with divergent host ranges: evidence from molecular and plant bioassay data. Biological Journal of the Linnean Society, 109, 165-180.

Southcott, R. V. (1946a). On the family Smarididae (Acarina). Proceedings of the Linnean Society of New South Wales, 70, 173178.

Southcott, R. V. (1946b). Studies on Australian Erythraeidae (Acarina). Proceedings of the Linnean Society of New South Wales, 71, 6-48.

Southcott, R. V. (1957). The genus Myrmicotrombium Womersley 1934 (Acarina: Erythraeidae), with remarks on the systematics of the Erythraeoidea and Trombidioidea. Records of the South Australian Museum, 13, 91-98.

Southcott, R. V. (1961). Studies on the systematics and biology of the Erythraeoidea (Acarina), with a critical revision of the genera and subfamilies. Australian Journal of Zoology, 9, 367-610.

Southcott, R. V. (1988). Two new larval Erythraeinae (Acarina: Erythraeidae) from New Zealand, and the larval Erythraeinae revised. New Zealand Journal of Zoology, 15, 223-233.

Southcott, R. V. (1995). A new larval erythraeine mite (Acarina: Erythraeidae) from Spain. Acarologia, 36, 223-228.

Stålstedt, J., Bergsten, J., \& Ronquist, F. (2013). "Forms” of water mites (Acari: Hydrachnidiae): intraspecific variation or valid species? Ecology and Evolution, 3, 3415-3435.

Šundić, M., Haitlinger, R., Michaud, J. P., \& Colares, F. (2015a). A new species of Erythraeus (Erythraeus) (Acari: Prostigmata: Erythraeidae) from central Kansas. Acarologia, 55, 41-48. doi:10. 1051/acarologia/20152152.

Šundić, M., Haitlinger, R., Petanović, R., Jovičić, I., \& Hakimitabar, M. (2015b). A new species of Erythraeus (Erythraeus) and new records of mites (Acari: Erythraeidae) from Serbia. Biologia, 70, 788-796.

Sutou, M., Kato, T., \& Ito, M. (2011). Recent discoveries of armyworms in Japan and their species identification using DNA barcoding. Molecular Ecology Resources, 11, 992-1001.

Tamura, K., Stecher, G., Peterson, D., Filipski, A., \& Kumar, S. (2013). MEGA6: molecular evolutionary genetics analysis version 6.0. Molecular Biology and Evolution, 30, 2725-2729.

Turk, R. (1981). Erythraeus styriacus n.sp., eine neue Milbenart aus Mittel- und Sudeuropa (Acari, Trombidiformes). Mitteilungen des Naturwissenschaftlichen Vereins für Steiermark, 111, 207-219.

Vences, M., Thomas, M., Bonett, R. M., \& Vieites, D. R. (2005). Deciphering amphibian diversity through DNA barcoding: chances and challenges. Philosophical Transactions of the Royal Society, B: Biological Sciences, 360, 1859-1868. 
Villesen, P. (2007). FaBox: an online toolbox for fasta sequences. Molecular Ecology Notes, 7, 965-968.

Waringer, J., Graf, W., Pauls, S. U., Vicentini, H., \& Lubini, V. (2008). DNA based association and description of the larval stage of Drusus melanchaetes McLachlan, 1876 (Trichoptera: Limnephilidae: Drusinae) with notes on ecology and zoogeography. LimnologicaEcology and Management of Inland Waters, 38, 34- 42.

Wendt, F.-E. (1996). On the ecophysiology of four species of Erythraeinae (Prostigmata: Parasitengonae) with special regard to osmotic regulation. In: R. Mitchell, D. J. Horn, G. R. Needham \& W. C. Welbourn (Eds.), Acarology IX, Proceedings (pp. 697-701). Ohio Biological Survey: Columbus

Whitworth, T. L., Dawson, R. D., Magalon, H., \& Baudry, E. (2007). DNA barcoding cannot reliably identify species of the blowfly genus Protocalliphora (Diptera: Calliphoridae). Proceedings of the Royal Society of London B: Biological Sciences, 274, 1731-1739.

Witte, H. (1991). Indirect sperm transfer in prostigmatic mites from a phylogenetic point of view. In R. Schuster \& P. W. Murphy (Eds.), The Acari: reproduction, development and life-history strategies (pp. 137-176). London: Chapman \& Hall.

Witte, H. (1995). Evolution and phylogenetic system of the Erythraeoidea (Prostigmata, Parasitengonae). In D. Kropczyńska, J. Boczek, \& A. Tomczyk (Eds.), The Acari: physiological and ecological aspects of Acari-host relationships (117-148). Warszawa: Dabor.
Wohltmann, A. (1998). Water vapour uptake and drought resistance in immobile instars of Parasitengona (Acari: Prostigmata). Canadian Journal of Zoology, 76, 1741-1754.

Wohltmann, A. (2000). The evolution of life histories in Parasitengona (Acari: Prostigmata). Acarologia, 41, 145-204.

Wohltmann, A. (2001). Closely related species of Parasitengonae (Acari: Prostigmata) inhabiting the same area: patterns facilitating coexistence. In: R. B. Halliday, D. E. Walter, H. C. Proctor, R. A. Norton, \& M. J. Colloff (Eds.), Acarology: Proceedings of the 10th International Congress of Acarology (pp. 121-135). CSIRO Publishing, Melbourne

Wohltmann, A., Gabryś, G., \& Mąkol, J. (2007). Acari: terrestrial Parasitengona inhabiting transient biotopes. In: Gerecke, R. ed. Süßwasserfauna Mitteleuropas, vol. 7/2-1, Chelicerata, Acari I. Spektrum Elsevier, München. 158-240

Zhang, G., \& Weirauch, C. (2011). Matching dimorphic sexes and immature stages with adults: resolving the systematics of the Bekilya group of Malagasy assassin bugs (Hemiptera: Reduviidae: Peiratinae). Systematic Entomology, 36, 115-138.

Zhang, H. C., Zhang, D., \& Qiao, G. X. (2008). Association of aphid life stages using DNA sequences: a case study of tribe Eriosomatini (Hemiptera: Aphididae: Pemphiginae). Insect Science, 15, 545-551.

Zhou, X., Kjer, K. M., \& Morse, J. C. (2007). Associating larvae and adults of Chinese Hydropsychidae caddisflies (Insecta: Trichoptera) using DNA sequences. Journal of the North American Benthological Society, 26, 719-742. 